IZA DP No. 10077

In God We Learn? Religions' Universal Messages, Context-Specific Effects, and Minority Status

Pierre-Guillaume Méon

Ilan Tojerow

July 2016 


\title{
In God We Learn? Religions' Universal Messages, Context-Specific Effects, and Minority Status
}

\author{
Pierre-Guillaume Méon \\ Université libre de Bruxelles (CEB) \\ Ilan Tojerow \\ Université libre de Bruxelles (CEB and DULBEA) \\ and IZA
}

Discussion Paper No. 10077

July 2016

IZA

P.O. Box 7240

53072 Bonn

Germany

Phone: +49-228-3894-0

Fax: +49-228-3894-180

E-mail: iza@iza.org

Any opinions expressed here are those of the author(s) and not those of IZA. Research published in this series may include views on policy, but the institute itself takes no institutional policy positions. The IZA research network is committed to the IZA Guiding Principles of Research Integrity.

The Institute for the Study of Labor (IZA) in Bonn is a local and virtual international research center and a place of communication between science, politics and business. IZA is an independent nonprofit organization supported by Deutsche Post Foundation. The center is associated with the University of Bonn and offers a stimulating research environment through its international network, workshops and conferences, data service, project support, research visits and doctoral program. IZA engages in (i) original and internationally competitive research in all fields of labor economics, (ii) development of policy concepts, and (iii) dissemination of research results and concepts to the interested public.

IZA Discussion Papers often represent preliminary work and are circulated to encourage discussion. Citation of such a paper should account for its provisional character. A revised version may be available directly from the author. 


\title{
ABSTRACT \\ In God We Learn? Religions' Universal Messages, Context-Specific Effects, and Minority Status*
}

\begin{abstract}
We study the relationship between major religious denominations and individuals' levels of education, using the World Values Survey. In a first step, running country-by-country regressions, we report first-time evidence that no single denomination has a universal effect on education. Each denomination has a positive and statistically significant effect in some countries, a negative and statistically significant effect in others, and a statistically insignificant effect elsewhere. In a second step, we relate the sign of the impact of a denomination in a country to whether the denomination is a minority in that country. We find that denominations that are a minority in a country are more likely to be associated with a higher level of education, and less likely to be associated with a lower level of education in that country. In both steps, the findings are independent from the specification of the regressions used in the first stage to determine the sign of the impact of denominations on educational outcomes. The finding of the second step is moreover robust to defining minority denominations using various thresholds. It is robust to controlling for whether the denomination is a state religion, for the country's level of democracy, per capita GDP, or level of education, to introducing denomination- and country- fixed effects, and to controlling for the identity of the largest other denomination in the country.
\end{abstract}

JEL Classification: $\quad$ 12, O5, Z1

Keywords: religion, education, minority

Corresponding author:

Ilan Tojerow

Université libre de Bruxelles

CP $114 / 02$

50, Av. F.D. Roosevelt

1050 Brussels

Belgium

E-mail: itojerow@ulb.ac.be

\footnotetext{
* We thank François Facchini, Victor Ginsburgh, Erich Gundlach, Petros Sekeris, participants of the European Public Choice Society conference in Cambridge and at the European Workshop in Political Macroeconomics, in Mainz, for helpful comments and suggestions, as well as participants in seminars at Tulane University, the University of Hamburg, the University of Portsmouth, the University of Liège, and Université libre de Bruxelles. The authors claim the sole responsibility for remaining errors and approximations.
} 


\section{Introduction}

Nearly one century after the publication of Max Weber's (1904) classic and after spending decades in the purgatory of economics, religion has once again resurfaced as an explanation of economic performance. Barro and McCleary $(2003$, 2006) have thus econometrically established a link between religiosity and growth in contemporary economies. Becker and Wössmann (2009) moreover report a cross-country association between per capita GDP and the share of Protestants in 1900. Various channels have been investigated to account for the correlation between specific religious denominations and economic performance, be it the role of the state, as argued by Kuran $(1996,1997,2004)$ or Platteau (2008), the impact of religion on values and attitudes towards economic activities, which is Weber's (1904) classic argument and has for instance been illustrated by Guiso et al. (2003) or Hillman (2007).

One implication of this impact of religion on attitudes concerns education, which directly promotes development. While the impact of education on development is uncontroversial, as Hannushek and Woessmann's (2008) survey shows, some denominations put more emphasis on education than others. Some denominations even promote literacy as a religious duty. For instance, Botticini and Eckstein $(2005,2007)$ recall that male Jews must be able to read the Torah in the Synagogue and teach it to their sons. Similarly, the principle of the priesthood of all believers implies that each Protestant should be able to read the Holy Scriptures.

All the arguments relating specific denominations to education share a common feature: They assume that denominations carry universal messages resulting in a universal incentive to acquire more, or less, education. They therefore imply that the impact of each denomination should be the same across countries. Yet, religion is also a social activity that could be considered as a club good (Iannaccone, 1992), hence we may assume that the same denomination may prompt its members to adopt different behaviors in different social contexts. A denomination may be dominant in one country and persecuted in others. It may be a majority in some countries and a minority in others. As a result, one may expect the impact of religious denominations to be context-dependent.

Unfortunately, that contention has received little attention so far. Most existing studies of the impact of religion on education are either country-specific or based on cross-country regressions. This is the case of Chiswick (1988) or Glaeser and Sacerdote (2008) for the 
United States, Brown and Taylor (2007) for the United Kingdom, or Blunch (2007) for Ghana. By construction, they cannot therefore compare the effect of religious denominations across countries. Some studies take a more macroeconomic standpoint, and are based on cross-country comparisons. This is what Guiso et al. (2003), Schaltegger and Torgler (2010), or Arruñada (2010) do, although they focus on attitudes rather than on education. However, in such regressions one runs the risk of attributing to religion differences that are related to other country-specific traits, such as geography or institutional quality. Most of all, those regressions force the effect of religious denominations to be the same across countries.

In this paper, we specifically let the impact of religious denominations differ across countries. To do so, we follow Guiso et al. (2003) and use the World Values Survey, which provides individual data on educational attainment, religious denomination, and religiosity in a large sample of countries. Unlike Guiso et al. (2003), we take advantage of the two-level structure of the World Values Survey to separately estimate the impact of religious denominations in all countries.

Our first key finding is that no single religious denomination has a universal impact on education. Each denomination has at the same time a positive and statistically significant effect in some countries, a negative and statistically significant effect in other countries, and a statistically insignificant effect elsewhere. In other words, we find the effect of religious denominations to be country-specific. The finding is robust to controlling for individuals' level of religiosity or not, and to focusing on individuals born in their country of residence. It holds equally for individuals below and over forty years old, and for male and female respondents.

In a second step, we investigate what determines the effect of a religious denomination in a country estimated in the first step. We more specifically test the role of the denomination's minority status. We expect that being a minority religion is a key determinant of the impact of a denomination on educational outcomes, although the sign of the effect on education of being a minority is ambiguous a priori. One the one hand, if minority denominations are discriminated against by teachers (Coate and Loury, 1993, Hannah and Linden, 2012), internalize negative stereotypes (Hoff and Pandey, 2006), have a limited access to social capital (Coleman, 1988), or oppose the values of the majority to avoid a loss in self-image (Akerlof and Kranton, 2000, 2002), then they should be more likely to result in lower educational outcomes. On the other hand, if investing in education is a way to cope with discrimination (Brenner and Kiefer, 1981), or if members of minority religions 
compensate for their lack of connections with the majority by stronger ties within the community (Coleman, 1988), benefit from positive stereotypes (Shih et al., 2002), or develop an identity that emphasizes academic effort (Akerlof and Kranton, 2002), then minority denominations may be associated with better educational outcomes.

To determine which effect prevails, we perform a cross-country study of the determinants of the marginal effect on education of religious denominations being significantly negative, significantly positive, or insignificant. In a series of multinomial logit regressions, we regress the impact of a religious denomination in a particular country to a dummy variable capturing the denomination's minority status in the country. We find that the likelihood of the impact on education of a denomination in a country being significantly negative is lower, and the likelihood of the impact being significantly positive larger, if the denomination is a minority. The finding is robust to a series of alternative definitions of minority denominations. It does not depend on the specification of the regressions used in the first stage to determine the sign of the impact of denominations on educational outcomes. It is robust to controlling for whether the denomination is a State religion, for the country's level of democracy, per capita GDP, or level of education. It resists introducing denomination- and country- fixed effects, and to controlling for the identity of the largest other denomination in the country.

Those results directly contribute to our understanding of the impact of religious denominations on education, by emphasizing that their impact is context-dependent and highlighting that it depends on being a minority. They more broadly contribute to our knowledge of the impact of culture, surveyed in Alesina and Giuliano (2015), and identity, surveyed by Kranton (2016). We show that the same cultural trait or identity characteristic, religious denomination, can have opposite effects across countries depending on the context.

To achieve those results, the rest of this paper is organized as follows. In the next section, we survey the literature on the impact of religious denominations on education. In the following section, we perform a country-by-country study of the impact of denominations on education. We observe wild differences across countries in the effect of religious denominations on education that are hidden by cross-country regressions. In section 4, we investigate the determinants of the sign and statistical significance of the marginal impact of religious denominations. The last section concludes. 


\section{The Impact of Religious Denominations on Education}

In this section, we discuss the possible relationship with education of the main religious denominations in our study. We first, provide arguments suggesting a uniform impact of those denominations across countries, then argue that their impact is likely context-dependent.

\subsection{The Implication of Religious Denominations for Education}

Some religious denominations have been interpreted as conveying universal norms and incentives to acquire more or less education. We review those denominations here, focusing in turn on Judaism, Islam, Protestantism, Buddhism, and Hinduism.

Judaism has often been assumed to emphasize education. An alternative explanation of the impact of Judaism on education, for instance put forward by Brenner and Kiefer (1981), is that Jews have historically been discriminated against in most parts of the world, and faced a risk of confiscation of their physical capital. As a result, they had an incentive to invest in education, which is a portable form of capital. This may have tilted the trade-off between the quantity and the quality of children towards quality, as argued by Chiswick (1988). Botticini and Eckstein $(2005,2007)$ stress the obligation for male Jews not only to be able to read the Torah in the Synagogue but more to the point to teach it to their sons. The stance of Judaism on general education is, however, more mixed. Hollander et al. (2003) report a theological debate on the issue. While some interpretations of the Torah recommend a balance between religious studies and worldly occupations, Hollander et al. (2003) claim that specific interpretations of the Bible encourage religious versus general studies. They recall that interpretations known as Midrashim claim that Jews should engage only in studies of the Torah, and not secular studies. Hollander et al. (2003), however, admit that mainstream Jewish thought holds a more balanced view, at least for the broad population, as opposed to selected scholars.

Bobrick (2001) argues that Islam is based on a more oral tradition than Judeo-Christian religions, resulting in lower incentives concerning literacy for Muslims. The word "Quran" means "recitation" in Arabic. Another feature of Islam that may negatively affect educational outcomes is the observance of Ramadan. Oosterbeek and van der Klaauw (2013) compare the results of Muslim and non-Muslim students in microeconomics tests at the University of Amsterdam, during years when Ramadam falls during the course and at another time. They 
find that one additional week of Ramadan exposure reduces the final grade of Muslim students for the microeconomics course by almost $10 \%$ of a standard deviation.

A key feature of Islam is that it offers religious education including basic reading of the Koran in madrasas and maktabs (Borooah and Iyer, 2005, and Chaudhury and Rubin, 2011). The impact of madrasas on non-religious education is ambiguous. On the one hand, religious schools devote time and effort to teaching religious subjects at the expense of secular subjects. Chaudhary and Rubin (2011) argue that, as a result, a greater prevalence of Muslim religious schools results in a wider Muslim-Hindu literacy gap in India. On the other hand, it can be argued that Muslim schools can provide a complementary educational system. In Bangladesh, state-registered and -financed madrasas called aliyah teach Bengali, English, mathematics and sciences, and their curricula are nationally defined by a national board that also runs national examinations (Asadullah and Chaudhury, 2010). A similar system was implemented in Indonesia (Newhouse and Beegle, 2006) and India (Borooah and Iyer, 2005). Whether chartered madrasas can provide a quality of education comparable to that of secular schools is a point of empirical debate. In some Indian states, madrasas are viewed as complements to the formal education sector (Borooah and Iyer, 2005). In Indonesia, Newhouse and Beegle (2006) could find no difference between religious and secular private schools in the public examination records of graduates of secondary junior schools. In Bangladesh, Asadullah et al. (2007) also find no difference between religious and secular schools at the secondary level, but observe a learning deficit among graduates of primary madrasas. Finally, Sander (2010) observes that Muslims in the US exhibit higher education than Protestants and Catholics.

Protestantism is usually believed to encourage literacy, because each believer should be able to have an unmediated access to the Holy Scriptures, in line with the principle of the priesthood of all believers. Becker and Woesmann (2009) recall that Martin Luther explicitly advocated education. He not only made it an obligation for rulers to build schools, but also urged parents to keep their children to school (Luther, 1524, 1530). Literacy, and education in general, are therefore hardwired in Protestant ethics, because they are a religious duty. Woodberry (2011) moreover argues that Protestant missionaries exported literacy by starting schools and pioneering phonetic alphabets and forms of writing accessible to a larger population.

Interestingly, although his main argument focused on work ethics, Weber (1904) cited his student Offenbacher's (1900) study on secondary school choices of Catholics, Protestants 
and Jews in the first chapter of his book, pointing to an over-representation of Protestants in institutions that prepared for technical and commercial occupations (Realgymnasium and Realschulen), while Catholics preferred a more general type of education (Gymnasium). Becker and Woesmann (2009) even argue that the impact of Protestantism on literacy accounts for most of the higher affluence of Protestants in XIX ${ }^{\text {th }}$ century Prussia.

Indeed, greater literacy rates among Protestants than Catholics have been repeatedly observed in various countries and times, such as the US in mid-XIX ${ }^{\text {th }}$ century (Go and Lindert, 2010), the first half of the $\mathrm{XX}^{\text {th }}$ century (Goldin and Katz, 2000), late XIX ${ }^{\text {th }}$ century's Ireland (Cipolla, 1969), or Finland (Markussen, 1990). More recently, Glaeser and Glendon(1998) found a stronger connection between religiosity and education among Calvinist Protestants than among Catholics, on contemporary US data. Blunch (2007) found, in his study of educational attainment in Ghana, that Protestant breeds of Christianity are associated with higher levels of education than Catholicism.

One should note, however, that Protestantism is heterogeneous, and that some Protestant denominations hold conservative views on the teaching of scientific disciplines, perceived as hostile to their faith and to the conviction that the Bible is inerrant, as Darnell and Sherkat (1997) or Beyerlein (2004) argue. Accordingly, Darnell and Sherkat (1997), Lehrer (1999), or Beyerlein (2004) have observed lower educational levels among conservative Protestant denominations than among other Protestant and non-Protestant denominations, using various surveys in the US. ${ }^{1}$

Roman Catholicism is the implicit reference group in Max Weber's (1904) book, and probably in most of the works devoted to the educational advantage of Protestants. ${ }^{2}$ It is therefore implicitly assumed to be less conducive to education. This implicit belief may contrast with the network of Catholic schools and higher education institutions around the world. Morey and Piderit (2010), for instance, count no less than 220 Catholic colleges and universities only in the United States. The Catholic Church also had developed an intellectual tradition on education and the role of reason, going back to the Early Church Fathers and the Middle Ages. However, while that tradition recognized that faith and reason were compatible,

1 Conservative Protestants are defined in those studies as three denominations: Fundamentalists, Pentecostal/Charismatic, and Evangelical. Christians. Beyerlein (2004) observes that the result that conservative Protestants are less educated is driven by Fundamentalist and Pentecostal Protestants, while Evangelicals exhibit above-standard educational attainments.

2 Weber's (1904) comments of Offenbacher's (1900) figures on the secondary school choices of Catholics, Protestants and Jews, for instance essentially focus on the difference between Protestants and Catholics. 
it considered that secular matters were subordinate to the Church's religious teaching. A specificity of the Catholic Church vis-à-vis Protestant denominations, and most other denominations, is that it has a central authority that can establish an official doctrine. It only started establishing its doctrine on education in the $\mathrm{XX}^{\text {th }}$ century, essentially in two documents (McClelland, 1996). The first is the encyclical Divini illius magistri published by Pope Pius XI in 1929. Although it acknowledged the role that the State could play in education, the encyclical recalled that secular education was subordinate to religious education and forbade Catholic children to attend laic schools. The second document is the Second Vatican Council's Declaration on Christian Education, entitled Gravissimum educationis and promulgated in 1965 by Pope Paul VI. It took a more moderate stance, emphasizing the positive roles of education and science, and featuring no explicit ban on secular or laic education. The overall position of the Roman Catholic Church on education therefore evolved over the course of the century, and its overall impact is ambiguous, especially as the official doctrine may be applied and interpreted in different ways in different countries or by different institutions.

The impact of other religions has, to our knowledge, received less attention, at least in the economics literature. One may contend that Buddhism has a positive impact on education, because of the importance it gives to universal access to the teaching of the Buddha. Ling (1984) argues that Buddhism is essentially a matter of teaching. The Buddha himself is portrayed as a teacher with an aim to address everyone without discrimination. As a result, in some traditions, Buddhism stresses the need to educate the largest number of people to read and write. In both Burma and Thailand, monasteries were thus instrumental in spreading literacy, Ling (1984) argues, resulting in high literacy rates. ${ }^{3}$ Secular governments even leveraged on those monasteries to spread education. Using contemporary data, Sander (2010) reports evidence that Buddhists having lived in the US at least since age 16 exhibit higher educational achievements than Protestants and Catholics. By contrast, Ling (1984) stresses that Buddhism's emphasis on universal access to the teaching of the Buddha stands in stark contrast with Hinduism, which sees parts of the population as unfit to the teaching of Brahmans in Hinduism.

\footnotetext{
${ }^{3}$ Ling (1984) recalls that in the first decade of the $\mathrm{XX}^{\text {th }}$ century, the rate of literacy for all Burmese males was 49 percent, while only 12 percent for Madras.
} 


\subsection{Country-Specific Impacts of Denominations on Education: the Role of Minority Status}

The views surveyed above imply that the impact of a religious denomination on education is independent from the context where it occurs. However, religion is intrinsically a social activity. Its impact on individual believers is therefore likely affected by their environment, and the behavior of others, be it members of the same denomination or of other groups in society. In other words, it is bound to be context-dependent. If the impact of a denomination is context-dependent, then one should isolate the dimensions of the context that determine its impact. In this section, we argue that there are strong reasons to expect that being a minority religion is a key determinant of the impact of a denomination on educational outcomes, although the impact may a priori be ambiguous.

At first pass, it is tempting to expect minority religions to lead to lower educational outcomes, because their members have more limited opportunities. The impact of minority denominations may, however, also be due to the attitude of their very members. First, in his paper introducing the notion of social capital, Coleman (1988) emphasizes the role of social capital for the accumulation of human capital. He defines social capital as the social structures that facilitate certain actions. Children from families that are integrated in a network may thus benefit from their families' network when acquiring human capital. Conversely, children who lack such a network would perform less well. In line with that contention, Coleman (1988) observes that children from families who have moved more frequently tend to drop-out of school more often. By definition, the networks of families belonging to minority denominations are more limited, and one may contend that their children have fewer opportunities to benefit from interactions with the rest of the population than children from the majority, and acquire less human capital.

Minority religions may also directly suffer from discrimination in education. Hannah and Linden (2012) document that graders tend to give lower grades to papers that are randomly attributed to lower caste students. The same mechanism may apply to students whose denomination is stigmatized.

Part of the effect of being a minority religion may also be driven by the reaction of the discriminated-against students. Investing less in the acquisition of human capital may be a rational response to discrimination, as Coate and Loury (1993) argue, if discriminated-against students face a larger cost of acquiring education than their non-discriminated counterparts. Behavioral mechanisms may also be a work. The Pygmalion effect initially documented by 
Rosenthal and Jacobson (1968) prompts pupils to conform to their teachers' expectations. Accordingly, pupils belonging to minority religions may suffer from their teachers' lower expectations, and end up acquiring less human capital. In a similar way, students may erroneously internalize a negative stereotype of inferiority. Hoff and Pandey (2006) thus observed that simply revealing that pupils were members of a disadvantaged caste reduced their performance in solving mazes on their own, and reduced their expectations of their own performance. By the same token, membership in a minority religion may lower the performance of pupils and students.

Akerlof and Kranton's (2000) theory of identity and its (2002) application to education provide a similar rationale. Akerlof and Kranton's (2002) model assumes that students not only maximize the pecuniary payoffs of education but also get utility from identifying with a group. To do so, they must share the attributes of the group and conform to its norms in terms of effort. Students will identify with the group that provides them the largest utility. Students from the leading group are those that best conform to the school's ideal. They therefore exert effort to reach the school's ideal and achieve academic success. However, identifying with the leading group is costly in terms of self-image if one does not share its attributes, for instance in terms of looks or social network. Students who do not have those attributes may therefore be better off identifying with another group that rejects the school's ideal, emphasizes low effort, and obtains lower academic success. Belonging to a minority religion may precisely be the type of attributes that prevents conforming to the ideal of the leading group, who typically belongs to the majority. Minority students may therefore choose to identify with a group that opposes the school's ideal, with negative consequences on their academic achievements.

While the mechanisms discussed so far suggest that members of minority religions should acquire less education, a closer look at the same arguments can also result in the opposite contention. First, Coleman's (1988) concept of social capital is not only quantitative. Families belonging to minority denominations may compensate their relative lack of connections with the rest of society by stronger relationships and a larger commitment to education within the family. Coleman's (1988) thus recalls the case of Asian immigrant families who purchased two copies of textbooks needed by the child, so that the mother would be able to help her child. In addition, the minority group may collectively compensate for its minority status by developing stronger community ties, resulting in more social capital, not less, and better educational outcomes. He thus relates the better performance of Catholic schools in the US to the role of the adult community around those schools. 
Disproportionately investing in education may also be a way to compensate for discrimination. In extreme cases, a minority facing persecution or the need to seek refuge would have an incentive to invest in education, because human capital, unlike physical capital, cannot be seized and is easily transferred across countries. Brenner and Kiefer (1981) use that line of reasoning to explain the finding that the level of education of Palestinians living in Arab countries after 1948 increased, and resembled that of Jews living in the US.

Stereotypes and identities may also encourage the acquisition of human capital. Indeed, all stereotypes are not necessarily negative. If a minority group is for instance perceived as "good at math" or "hard-working", then teachers may raise their expectations, resulting in a positive Pygmalion effect for the minority group. Shih et al. (2002) report experimental evidence that subtly activated positive stereotypes can enhance academic performance of the target group. ${ }^{4}$

Akerlof and Kranton's $(2000,2002)$ model of identity performance also produces mixed predictions. Not being able to identify with the leading group may enhance academic performance for students who identify with a group that lacks the attributes of the leading group but values academic performance. The 2002 model applied to academic performance considers three groups of students, referred to as jocks, nerds and burnouts, and two types of skills, for simplicity looks and academic ability. Jocks are the leading group, insofar as they get the largest utility from identifying with the group, followed by nerds, and burnouts. The key group attribute is looks for jocks and academic ability for nerds, while burnouts have no specific attribute. The model implies that a student whose looks do not conform to those of jocks will opt to identify with one of the two other groups. Only if her ability is too small will she identify with burnouts. With sufficient ability, she will identify with nerds. As that group emphasizes academic performance, students identifying with it will have an incentive to increase academic effort to conform to the group's ideal, thereby improving their academic performance. The model therefore implies that if students from a religious minority are prevented from identifying with the leading crowd, they may have an incentive to increase academic effort. Their minority status would thus result in the acquisition of more human capital, not less.

\footnotetext{
${ }^{4}$ Positive stereotypes are, however, no unmitigated blessing. Shih et al. (2002) report that positive stereotypes can indeed reduce academic performance if they are blatantly imposed on their targets. See Czopp et al. (2015) for a survey of the effects of positive stereotypes.
} 
In a similar way, Iannaccone (1992) and Berman (2000) emphasize that religion is a club good, insofar as the benefit from religious participation depends not only on individuals' own inputs but also on the inputs of others. The impact of a given denomination on behavior in general therefore depends on the size of the religious community or the need to distinguish its members from the rest of society. Berman (2000) accordingly argues that the lengthening of religious studies (yeshiva) among ultra-orthodox Jews in Israel is a rational reaction to the difficulty to signal commitment to the ultra-orthodox community in a predominantly Jewish society. Berman (2000) remarks that ultra-orthodox Jews with the same geographic origin as those who live in Israel but who live in countries that are not predominantly Jewish, for instance in Central and Eastern Europe, Canada or the US, stop attending yeshiva much earlier than in Israel. Berman's (2000) interpretation of this finding is that sending a signal that one belongs to the ultra-orthodox community is much easier in predominantly non Jewish societies than in a society that is predominantly Jewish. The impact of belonging to the ultraorthodox denomination therefore has a clear context-dependent effect on religious education. It is weaker in countries where Jews are a minority. As attending yeshiva comes at the cost of secular education, one should expect ultra-orthodox Jews to have an incentive to acquire more secular education in countries where Judaism is a minority religion. The same line of reasoning may apply to other denominations elsewhere. What it implies is that not being a minority may adversely affect the acquisition of secular human capital.

Chaney (2011) suggests a final mechanism associating a minority religion with a greater emphasis on education, based on the reaction of religious elites, at least in the case of Islam. He argues that fostering logical methods poses a dilemma to Islamic elites: on the one hand, the art of discussion, ilm al-kalam, can contribute to attract converts. On the other hand, it may also lead some Muslims to question the authority of religious elites. Choosing between the two therefore depends on the context. Where Islam is a minority, or still new, it is more important to attract converts. Conversely, where Islam is an established majority, it is more important to secure the position of the religious elite. He argues that this mechanism sheds light on the behavior of the Ottoman Empire in Anatolia. When the Ottoman Empire conquered the initially Christian region in the $\mathrm{XIV}^{\text {th }}$ and $\mathrm{XV}^{\text {th }}$ centuries, they first encouraged ilm al-kalam, leading to a period of scientific achievements. Once the region had become predominantly Muslim, religious elites supported a move away from rational sciences, eventually leading to a scientific decline. The upshot of this argument is that the stance of the 
Muslim elites on education in the Ottoman Empire depended on whether Islam was a minority or not.

The notion that the impact on education of a denomination depends on its minority status, though appealing, has received little direct empirical attention, but indirect evidence suggests that minority religions tend to perform better than other denominations in terms of academic achievements. For instance, Sander (2010) reports that Jewish, Muslim, and Buddhist residents in the US have higher educational achievements than Protestant and Catholics, while their religions only represent $1.4,0.5$, and 0.5 percent of the population.

Chaudhary and Rubin (2011) report similar evidence for Muslims in India. They note that Muslims living in districts with more Muslims have lower literacy rates. They for instance note that in Bengal 21.1 percent of Hindu males are able to read and write but only 10.9 percent of Muslim males. In Madras, where the share of Muslims is much lower, literacy rates of Hindus and Muslims are comparable. Borooah and Iyer (2005) made similar findings.

\section{Global versus Country-Specific Effects: an Estimation}

In this section, we investigate the impact of specific religious denominations on education. After presenting the data, we apply the same method as standard cross-country studies, and simply regress individuals' levels of education on a dummy variable capturing their confession, thereby forcing the impact of each denomination to be the same across countries. These regressions only serve as a benchmark against which to assess our key contribution. The key contribution of this section appears in the following sub-section, where we allow the impact of each denomination to be country-specific, and report major differences across countries.

\subsection{Data}

Our key data was retrieved from the World Values Survey. The survey has been carried in a large number of countries since 1981. It results in a two-level dataset, where the country of individual respondents can be identified.

The World Values Survey covers a lot of issues, and more specifically contains questions about education, religion, and religiosity. Respondents are asked to indicate their level of education. It results in a variable that can assume three values: lower education, middle education, and higher education. An individual is considered to have a lower 
education if he/she inadequately completed elementary education, completed elementary education, or has not completed secondary school. The individual falls in the middle category if he/she has completed secondary school or has some university-preparatory type or secondary intermediate general qualification. The individual will be considered as having received higher education if he/she has a university degree or at least a higher education with a lower-level tertiary certificate.

The World Values Survey also contains information about respondents' religious denominations. As there are many denominations across the world, which would result in many denominations appearing only in one country, we pooled denominations together following Guiso et al.'s (2003) classification: Catholic, Christian-Protestant, ChristianOrthodox, Buddhist, Muslim, Jewish, and Hindu. Other less frequent religions were pooled under the label "other religions", and we kept a separate category for respondents reporting no religious affiliation.

*** Insert Table 1 around here ***

Table 1 presents statistics of our final sample of 147,049 respondents, distributed across 77 countries and 3 waves of the World Values Survey. ${ }^{5}$ The top of the table reports the worldwide distribution of religious denominations. It appears that more than $40 \%$ of the individuals in our sample are affiliated with one of the Christian denominations, i.e. Catholicism, Protestantism and Christian Orthodoxy. More than 50\% go to religious services once a year or less, while $30 \%$ go to services at least once a week. The rest of the table provides for the distribution across education levels and for demographics.

\subsection{Global Estimates}

As a first step, we relate at the global level individual educational levels to religious denominations using a cross-country regression similar to those of Guiso et al. (2003), Schaltegger and Torgler (2010), or Arrunada (2010). We therefore estimate the following ordered logit model for each denomination:

\footnotetext{
${ }^{5}$ See Table A1 in the Appendix for details on the sample composition broken down by country.
} 
Where:

- Education $i$ is the ordered variable measuring respondents $i$ 's level of education;

- $y \in$ (lower education, middle education, and higher education);

- Denomination $_{k i}$ is a dummy variable capturing whether respondent $i$ 's religious denomination is denomination $k$, where $k \in$ (Catholic, Christian-Protestant, ChristianOrthodox, Buddhist, Muslim, Jewish, and Hindu, Other religions, and no religious affiliation);

- $C_{i}$ is a vector of control variables controlling for respondent $i$ 's demographics and religiosity: Age, gender, marital status, income (by decile), and social class. We include a dummy variable set to one if respondent $i$ declares to be a religious person, and three dummy variables controlling for respondent $i$ 's church attendance: one capturing whether the respondent goes to church once a week, another if he/she goes to church once a month, and a third if he/she goes to church one a year;

- Country $y_{i}$ is a fixed country effect;

- Year $i$ is a dummy variable controlling for the survey wave in which the respondent filled in the questionnaire.

We control for religiosity to distinguish its impact from that of denominations. By doing so, we distinguish the intensity of religious practices, which has been found to correlate with education for instance by Mocan and Pogorelova (2014), from the affiliation to a given denomination.

Country effects are included to control for systematic differences across countries. As a result, the observed effects of religious denominations are at work within countries, and can for instance not be attributed to differences in education policies.

As the dependent variable is an ordered discrete variable, we estimate the relationship between education and religious denomination using an ordered logit model. Each religious denomination is considered in a specific regression. This means that the impact that each denomination is assessed by comparing it to a reference group consisting of all other respondents. However, it is clear from expression (1) that the coefficient of each denomination is by construction the same across countries. The result of estimating expression (1) should therefore be interpreted as measuring the average impact on education at the global level of belonging to a given denomination. 
The result of those regressions are reported in Table 2, where each column reports the results for one denomination. The coefficient of interest is the coefficient of the denomination dummy, which captures a different denomination in each column. It for instance captures whether respondent $i$ is a Catholic in column 1.1 and whether he/she is a Protestant in column 1.2. The sign of the coefficient of the dummy variable captures whether at the global level belonging to a denomination increases or decreases the probability to have acquired a higher level of education.

*** Insert Table 2 around here ***

Most religious denomination dummies exhibit an insignificant coefficient. That is the case of the Catholic, Protestant, Hindu, Buddhist denominations, and of denominations pooled under the label other denominations. Those denominations therefore appear unrelated to respondents' levels of education worldwide.

However, we observe that the Jewish and Christian Orthodox dummies exhibit positive coefficients that are significant at the five and one-percent levels respectively. Jewish and Christian Orthodox respondents accordingly have a higher level of education on average at the global level. Conversely, the Muslim dummy bears a negative coefficient that is negative at the one-percent level, suggesting that being Muslim is on average associated with a lower level of education. Table 2 also shows that being a non-religious person bears a positive sign significant at the one-percent level, meaning that non-religious persons have on average a higher level of education.

\subsection{The Heterogeneity of the Impact of Religious Denominations on Education}

Table 2 seems to deliver a clear message: Most religious denominations seem unrelated to the level of education with one negative exception, Islam, and two positive exceptions, Judaism and Christian Orthodoxy. These findings at the global level however rest on the assumption that the marginal impact of each denomination is the same across countries. This assumption makes sense if one believes that religious denominations convey universal messages and prescriptions. Now, our specifications so far force the marginal effect of religious denominations to be the same across countries. As a consequence, the estimates of Table 2 may hide important cross-country heterogeneities. In fact, they simply prevent us from testing the notion that religious denominations have universal effects. 
To test that notion, one has to allow the marginal effect of each denomination to differ across countries. With this end in view, we therefore performed another set of regressions. We still regressed the level of education achieved by individual respondents on their religious denomination and a series of control variables, but instead of pooling all countries together, we ran the following regression for each denomination $k$ and each country $j$ :

$\operatorname{Prob}\left(\text { Education }_{i}=y\right)_{j k}=f\left(\right.$ Denomination $_{k i}, C_{i}$, Year $\left._{i}\right)$

Where variables are defined as in Expression (1). The key difference between the two specifications is that Expression (2) includes no country fixed effect, because it is estimated separately for each country.

As we considered one denomination at a time and up to 72 countries, we ran 502 regressions and obtained as many country-denomination-specific marginal effects, Effect $t_{j k}$. Reporting all those regressions would be tedious and impossible to interpret. What really matters instead, is the distribution of coefficients across countries for each denomination. We therefore report coefficients according to their sign and significance. ${ }^{6}$ Those coefficients must be interpreted as capturing the country average effect on education of a given denomination, as opposed to the global average effect estimated in previous sub-section and in the rest of the literature.

*** Insert Figure 1 around here ***

Figure 1 summarizes the distribution of the coefficients of religious denominations resulting from the estimation of a parsimonious model, where the level of education is explained by the respondent's religious denomination, and individual demographic characteristics, namely age, gender, marital status, income, social class, and religiosity when significance is set at the ten-percent threshold. ${ }^{7}$ A simple glance at the figure reveals that each religious denomination has a significantly negative effect in some countries, and an insignificant or significantly positive effect in others.

\footnotetext{
${ }^{6}$ As the estimated model is a logit model, we cannot interpret their magnitude.

7 Table A2 in the appendix exhaustively reports the specific sign and significance of the coefficient of each denomination in each country.
} 
To be more specific, Figure 1 shows that Catholicism has a significantly negative impact on education in 11.1 percent of the countries in our sample where there are Catholics, and a significantly positive impact in 29.2 percent of those countries. Being Protestant has a significantly negative impact in 20.3 percent of countries, and a significantly positive impact in 29.0 percent of countries. This finding is at odds with the view that Protestant ethics should give an incentive to acquire more education everywhere. Being a Christian Orthodox results in a lower level of education in 20.8 percent of countries and a higher level of education in 22.6 percent of countries. Buddhism can also have a negative effect, in 25.6 percent of countries, and a positive effect, in 30.2 percent of countries. Being Muslim reduces the level of education in 39 percent of countries, but increases it in 10.2 percent of countries. Being Jewish has a negative effect on the level of education in 13 percent of countries, while it has a positive impact in 26.1 percent of countries. Again, this is at odds with the view that Judaism provides a universal incentive to acquire education. Being Hindu is associated with a lower level of education in 22.2 percent of countries, but has a positive effect in 29.6 percent of countries. The Other denominations category also splits evenly between a negative and a positive impact, which is somewhat unsurprising, as this category is by definition heterogeneous. Finally, even the impact of reporting no religious denomination at all varies across countries. It is negative in 5.6 percent of countries, insignificant in 62.5 percent, and positive in 31.9 percent of countries.

*** Insert Table 3 around here ***

Table 3 complements Figure 1 by considering the three standard levels of statistical significance. The top panel of the table considers statistical significance at the one-percent level, the middle panel statistical significance at the five-percent level, and the bottom panel statistical significance at the ten-percent level. The first three columns report the share of coefficients corresponding to each sign, and the fourth column the number of regressions run for each denomination. This number varies across denominations, because a denomination has to be present in a country for the regression to be performed in that country. For instance, the impact of being Hindu could not be assessed in Algeria, simply because there was no respondent reporting being Hindu in that country.

A cursory look at Table 3 reveals that no cell in the table features a zero. This confirms the finding of Figure 1 that each religious denomination can have a significantly 
negative, significantly positive, or insignificant effect depending on the country under consideration. Moreover, the finding holds regardless of the level of significance. It even holds in the top panel of Table 3, where the level of significance is set at the one-percent level, and the number of insignificant coefficients is therefore mechanically larger than in the other two panels.

\subsection{Robustness Checks}

In this sub-section, we check the robustness of our findings along two dimensions. The first dimension is the robustness of the finding that the effect of religious denominations is heterogeneous across countries. The second dimension is that the sign and significance of the effect of a denomination in a country must be robust too. Table 4 therefore reports not only the distribution of coefficients for various alternative specifications but also the percentage of coefficients that are categorized in the same way as with the baseline specification. To facilitate comparisons, the first column of the table reports the distribution of coefficients obtained with the baseline specification. All the results reported in the table use the tenpercent level of significance.

One may argue that, by controlling for religiosity, the baseline specification may strip denominations of their effect, because it operates through religiosity. To make sure that it is not the case, Table 4 reports the results of estimating the baseline specification, but without controlling for religiosity. The outcome of this robustness check is reported in the first column of the table. Again, each denomination can have either a significantly negative impact, an insignificant impact, or a significantly positive impact in at least some countries of the sample. Moreover, for all religious denominations, the share of coefficients that are categorized in the same way exceeds 90 percent of countries.

One may be concerned that income is endogenous to education, and that it correlates with both the level of education and the religious denomination of an individual. To make sure that our results are not driven by the inclusion of income in the set of independent variables, we estimate another specification that does not control for income. The second column of Table 4 reports the distribution of coefficients when income is not controlled for in Equation 2. It confirms our key result that no denomination has the same marginal effect across countries. Furthermore, the sign and significance of coefficients is identical to those obtained with the benchmark specification in 91 percent of countries or more for all denominations. 
Because the role of religion may have changed over time, we distinguish individuals by age. Hence, we run all the country-denomination regressions separately for respondents below and above the age of 40 . The outcomes of the two series of regressions are reported in Columns 4.4 and 4.5 of Table 4 . The distribution of coefficients in the two columns is similar. In addition, in both columns the distribution of coefficients remains similar to the benchmark distribution.

Because some religions ascribe different roles to men and women, our results may in fact capture a gender gap. To check whether it is the case, we consider two subsamples made up of only female or male respondents in Columns 4.6 and 4.7 of Table 4. Again, the distribution of coefficients is similar across the two columns, and more importantly identical to the benchmark categorization in 70.5 to 92.3 percent of countries.

Because in some countries, followers of a particular denomination may have migrated in the country, our results may capture the effect of migration rather than denominations. The third wave of the World Values Survey allows distinguishing respondents who are not native of their country of residence. We therefore dropped non-natives from the sample to run the benchmark specification only on natives. Although the size of the sample substantially shrinks and the period of observation is different, Column 4.8 of Table 4 reports that a majority of coefficients are identical to those obtained using the benchmark specification.

Finally, higher education may result in, or be the outcome of, religious conversions. To make sure that our results are not driven by the impact of education on the choice of a religious denomination, we focus on the subset of respondents who were raised religiously. The information is only available in the third wave of the World Values Survey, which is why we run our regressions on that specific wave. The results are reported in the last column of Table 4 . They are very close to those of the benchmark. Coefficients fall in the same category as for the benchmark regression in at least 94 percent of countries for each denomination.

The main message from the above results is that no religious denomination has a homogeneous effect across the world. In other words, the effect of religious denominations is country-specific. Admittedly, some denominations, e.g. Islam, exhibit a more frequent negative effect, and others, like Judaism, exhibit a more frequent positive effect. However, Islam is associated with more education in 13.6 percent of countries in our sample, and Judaism is associated with less education in 10.9 percent of countries. 
If the impact of religious denominations is not universal but country-specific, the key question then becomes to determine what may drive a religious denomination to have a negative effect in one country, a positive effect in another, and be plainly insignificant elsewhere. This is the question that we address in the next section.

\section{Explaining Heterogeneity: the Role of being a Minority}

\subsection{Baseline Results}

To explain why a religious denomination may have a positive effect on education in some countries and a negative or insignificant effect in others, we use the outcome of previous section as our dependent variable. Specifically, we use as observation the outcome of each regression reported in Table 3 and create a categorical variable capturing the sign of the marginal effect of denomination $j$ in country $i$. Each observation is therefore a denomination-country pair. The categorical variable can take three modalities: negative and significant at the ten-percent level, insignificant at the ten-percent level, or positive and significant at the ten-percent level. We then estimate the following multinomial model:

$$
\operatorname{Prob}\left(\text { Effect }_{j i}=x\right)=f\left(\text { Minority }_{j i}, C_{j i}\right)
$$

where :

- Effect $t_{j i}$ is the sign of the coefficient of denomination $j$ in country $i$ in Table 3;

- $x \in$ (significantly negative, insignificant, significantly positive);

- Minority $y_{j i}$ is a dummy variable signaling whether denomination $j$ is a minority religion in country $i$;

- $C_{j i}$ is a vector of control variables.

Our key explanatory variable of interest is denomination $j$ 's minority status in country $i$, because we expect members of minority religions to face incentives that differ from those of members of majority religions. Table 5 below reports the number of countries in our sample where each denomination is present, and the number and shares of countries where each denomination is a minority. Here, we define a denomination as a minority if its share of followers in a country is smaller or equal to five-percent according to the World Values Survey. It shows that, while the frequency varies across denominations, each denomination is a minority in some countries. Judaism stands out, as it is a minority in every country in our sample. 
We control for a series of country characteristics that can be subsumed into two groups. The first group of variables describes a country's type of government and government policy. Kuran (1996, 1997, 2004) and Platteau (2008) emphasize the relationship between Islam and the State. Specifically, we define a dummy variable indicating whether denomination $j$ is a State religion in country $i$. We used the list of State religion provided by Barro and McCleary (2005), and set the dummy variable to one when the State religion of Country $i$, if any, corresponded to denomination $j$. We also control for a country's degree of democracy, as measured by the PolityIV index (Marshall et al., 2011). We expect religious denominations to matter less in more democratic countries, because democracy allows for a better representation of all the components of society. The first group of variables also contains a measure of the official hostility of the government towards religion, retrieved from the Religion and State Project carried out by the Association of Religion Data. That variable increases with hostility. The effect of that variable is a priori ambiguous. On the one hand, one may expect that more secular governments foster education for all citizens, regardless of their denomination. In that case, hostility of the government towards religion should reduce the influence of denominations on education. On the other hand, if the government's hostility leads to bar education to religious pupils, then the variable should correlate positively with the probability that a denomination has a negative effect on education.

The second set of country characteristics captures a country's level of development. We thus control for per capita GDP at purchasing power parity retrieved from the Penn World Tables dataset. One may expect that more developed countries have a better education infrastructure, and that religious denominations therefore matter less in those countries. Also, religiosity has been found to decrease with income (see e.g. McLeary and Barro, 2006) although the effect may not be causal, as Becker and Woessmann (2013) argue. Finally, Bettendorf and Dijkgraaf's (2010) finding that the impact of religiosity on individual income is conditional on the income level of individuals' country of residence may also apply to the impact of religious denominations on education. We also control for the average level of education in the country. The idea here is that religious denominations could simply not matter if the entire population was educated. This intuition is in line with the finding of Borooah and Iyer (2005) that differences in the school enrolment of boys among Muslim and 
Hindus are essentially observable in the poorer regions of India, where school enrolments are low. We therefore expect the role of religious denominations to be more limited in countries where the average level of education is higher. Specifically, the likelihood of religious denominations having a significant positive or negative effect should be lower in countries with a higher level of education. We therefore control for the average number of years of secondary education in the population, as measured by Barro and Lee (2013).

Finally, we control for the number of observations used in regressions in each country. In our sample that number ranges from 282 in the Dominican Republic to 6745 in South Africa. The smaller the number of observations, the larger standard errors, and the smaller $\mathrm{t}$ statistics. As a result, the likelihood of observing an insignificant coefficient is larger the smaller the number of observations. We therefore control for that variable in all regressions to avoid our results being biased by a statistical artifact.

We estimate Equation 3 as a multinomial logit model, because the dependent variable is an unordered trichotomous variable. In all regressions, the reference category is the category corresponding to denomination $j$ having no significant effect on education in country $i$.

As there is no standard threshold to define a minority religion, we first estimate Equation 3 using alternative definitions of the minority dummy variable. Specifically, we create a dummy variable taking the value one in denomination-country pair $j i$, if the share of respondents in the World Values Survey reporting denomination $j$ as his/her religion in country $i$ is lower than a given threshold, and consider in turn thresholds ranging from one to fifty percent. Table 6 reports the results of estimating Model 3 using a multinomial logit regression with those alternative dummy variables. The bottom row of the table reports the number of minority denominations in the sample obtained with each definition, which unsurprisingly increases as the threshold to define a minority religion increases.

\section{*** Insert Table 6 around here $* * *$}

The top panel of Table 6 reports the coefficients measuring the impact of the explanatory variable on the probability that denomination $j$ has a positive effect significant at the ten-percent level in country $i$. Conversely, the bottom panel of Table 6 reports the coefficients measuring the impact of the explanatory variable on the probability that 
denomination $j$ has a negative effect significant at the ten-percent level in country $i$. The unreported modality pertains to the coefficient not being significant at the ten-percent level.

The first column of Table 6 reports the result of estimating Equation 3 when a denomination is assumed to be a minority in a country if less than one percent of respondents claim to belong to that denomination. We observe that that variable exhibits a positive coefficient in the top panel and negative coefficient in the bottom panel of the column and that both are significant at the ten-percent level. This implies that if being a minority religion decreases the probability for religion $j$ to be negatively associated with a lower level of education in country $i$, and that it increases the probability that the religion be positively associated with a higher level of education in the country.

Columns 6.2 to 6.7 of Table 6 perform the same regression with increasing levels of the threshold used to define a minority religion: $5 \%, 10 \%, 20 \%, 30 \%, 40 \%$, and $40 \%$ respectively. They exhibit the same pattern as the first column. Specifically, the coefficient of the minority dummy is positive and statistically significant at the ten-percent level or beyond in the top panel of each column, and negative and statistically significant at the ten-percent level or beyond in the bottom panel of each column. There are only to exceptions. In Column 4 , where the minority threshold is set to 20 percent, the coefficient of the minority dummy is insignificant at standard levels of confidence in the top panel of the column. It is, however, significantly negative at the ten-percent level in the bottom panel. Conversely, when the threshold is set to 30 percent, in Column 5 , the coefficient fails to be statistically significant in the bottom panel of the column, but is positive and significant at the five-percent level in the top panel.

In the last column of Table 6 , we experiment with a continuous way to capture a denomination's minority status in a country. We compute the share in the country of all the other denominations, which is also the complement to one of the share of the denomination of interest. That share increases if the denomination of interest becomes a smaller minority. Again, we observe that that measure of minority status positively correlates with the probability of denomination $j$ to have a positive effect on education in country $j$, and correlates negatively with the probability of the denomination having a negative effect on education in the country.

Table 6 therefore sketches a consistent pattern of the effect of minority religions on the educational achievement of their members a country. Minority religions are less likely to 
reduce and more likely to increase the educational achievement of their members with respect to their fellow citizens. The finding is robust to various definitions of minority denominations.

Table 6, however, allows comparing alternative definitions of the minority religion dummy variable. Specifically, we observe that the results that are the most statistically significant are the results obtained when the threshold for a denomination to be considered as a minority is set to five percent. In that particular case, the coefficient of the dummy variable is significant at the five-percent level in the top panel and significant at the one-percent-level in the bottom panel of Table 6 . This suggests that the five-percent threshold best identifies minority religions. We therefore use it as our benchmark in the rest of this paper.

\subsection{Robustness Checks}

The dependent variable in Equation 3 is a categorical variable defined on the outcomes of a series of regressions run in different countries with the same specification of Equation 2. However, the result may be specific to that specification. In Section 2, we experimented with a series of alternative specifications of Equation 2, and showed that the finding that no denomination had the same effect across countries was robust to using alternative specifications. However, one may still be concerned that the results of Table 6 are driven by the particular specification of Equation 2 used to define the dependent variable.

To make sure that this is not the case, we therefore estimated Equation 3 using definitions of the dependent variable obtained in turn from all the specifications of Equation 2 estimated in Section 2. The results of those estimations are reported in Table 7.

Our benchmark specification of Equation 2 controls for an individual's level of religiosity, which may interact with education. We therefore estimated Equation 2 without controlling for religiosity, use that specification to define the dependent variable in Equation 3. Column 7.1 of Table 7 reports the outcome of that estimation. The minority dummy still exhibits a positive sign, significant at the ten-percent level, in the top panel of the column, and a negative sign, significant at the one-percent level in the bottom panel, in line with our benchmark estimates. Column 7.2 reports the outcome of the same exercise, but drops income in the estimation of Equation 2 instead of religiosity. Here, the coefficient is statistically insignificant in the top panel of the column, but still negative and significant at the onepercent level in the bottom panel. 
Columns 7.3 and 7.4 distinguish respondents by age, as one may argue that the role of religion may have changed over time. We therefore estimated Equation 3 separately for respondent below and above 40 years. Yet, the results of the two columns are similar. In both columns, the minority variable is statistically significant at the one-percent level in the top panel of the table, and insignificant in the bottom panel.

Finally, Columns 7.5 and 7.6 provide separate results for male and female respondents. Again, and possibly surprisingly, we find similar results for the two genders, suggesting that the effect of being a minority religion does not operate through a differential effect for men and women. More precisely, we find that the minority variable is statistically significant at the one-percent level in the top panel of the table, and insignificant in the bottom panel for both genders.

One may be concerned that the impact of being a minority denomination may be driven by the behavior of immigrants, who often belong to a denomination that differs from the denomination of the host country, which may confound or results. We therefore estimated Equation 2 on the subset of survey respondents who were born in their country of residence. ${ }^{8}$ Column 7.7 reports those results. It confirms the positive and statistically significant effect of being a minority denomination in the top panel of Table 7. The impact, however, turns out statistically insignificant in the bottom panel.

So far, we have relied on bivariate regressions. To make sure that our results are not driven by an omitted variable bias in Equation 3, we control for a series of factors. As there is no specification to guide us in the choice of the list of control variables to use when estimating Equation 3, we started by including each variable in turn, before including them all in the same regression. The outcomes of those regressions are reported in Table 8.

\section{*** Insert Table 8 around here ***}

In the first column, we control for the dummy variable indicating whether denomination $j$ is a State religion in country $i$. In the second column of Table 8, we control

\footnotetext{
${ }^{8}$ Note that the information was only available in the third wave of the World Values Survey, while the main specification aggregates information from several waves.
} 
Country $i$ 's level of democracy as measured by the PolityIV index. In the third column, we control for the country's PPP GDP per capita. In Column 8.4, we control for the country's years of schooling. In Column 8.5, we control for the number of observations in country $i$. In Column 8.6, we control for no specific variable, but include denomination fixed effects to control for any effect of any denomination that would be constant across countries. Column 8.7 controls for all variables at the same time, and Column 8.8 adds denomination fixed effects to the list of control variables. Column 8.9 replaces the control variables that are country-specific by country fixed effects, while controlling for denomination fixed effects at the same time.

The impact of a religious denomination may depend on the denomination with which it competes. For instance, being Christian orthodox in a country where the main other denomination is Catholicism may result in very different incentives than being Christian orthodox where the main other denomination is Islam. This source of heterogeneity is not controlled by country- or denomination-fixed effects, because it is specific to denominationcountry pairs. We therefore controlled for denomination $j$ 's main alternative in country $i$. Specifically, for each denomination-country pair $(j, i)$, we defined eight dummy variables coding the largest denomination in country $i$ beside denomination $j$. For instance, the first dummy variable is set to one for Country $i$ and Denomination $j$ if Catholicism is the main denomination beside Denomination $j$, and set to zero elsewhere. We defined such a dummy variable for each denomination in our sample. Column 8.11 reports the result of a regression controlling for those dummy variables, together with country- and denomination- fixed effects. As an ultimate robustness check, Column 8.12 complements Column 8.11 by controlling for the other country-denomination pair dummy, namely State religion.

The results reported in Table 8 are homogeneous. In the nine columns of the table, the coefficient of the minority dummy variable is positive and significant at the five-percent level or beyond, signaling that all specifications imply that members of minority religions tend to accumulate more education than their fellow citizens of another denomination.

Similarly, the bottom panel of Table 8 implies that when a religion is a minority in a country, the members of the religion are less likely to have acquired less education than their fellow citizens. The coefficient of the minority variable in the bottom panel of Table 8 is in general negative and statistically significant well beyond the ten-percent level. In Columns 8.7 and 8.8 , where the all set of control variables are controlled for, the coefficient turns out insignificant. However, one should remark that the number of observations in the regression 
is also limited by data availability. When those variables are replaced by fixed-country effects, which allows controlling for all country-specific omitted variables without reducing the size of the sample, the coefficient of the minority dummy is negative and significant at the one-percent level.

A by-product of Table 8 is to allow assessing the impact of control variables. Unlike the minority dummy variable, other control variables are in general statistically insignificant. One exception is the variable that measures the average number of years of schooling in the population. That variable is statistically insignificant in the top panel of Table 8 but bears a negative and statistically significant at the ten- or five-percent level, depending on the specification. This suggests that any denomination is less likely to have a negative impact on its members' educational achievements in a country if the average level of education in that country is larger, which is in line with our expectations.

The dummies capturing the main alternative denomination are nearly always statistically insignificant. Moreover none is significant in more than one specification, which is why we do not report their coefficients. The regressions reported in Table 8, however, show that controlling for the main alternative denomination does not affect our main conclusions. We observe that that the minority religion dummy variable exhibits a positive coefficient in the top panel and negative coefficient in the bottom panel of the column and that at least one of them is statistically significant.

\section{Concluding Remarks}

We have used the World Values Surveys to identify the impact of major religious denominations on individuals' levels of education in a large sample of countries. Two main results emerge from our results.

First, no denomination has a uniform effect on the level of education of its members across countries. In other words, we find that each denomination correlates positively with education in some countries, negatively in other countries, and does not correlate with education in others. In a nutshell, no denomination has a universal effect on education.

The second main result is that the propensity of a denomination to have a positive, negative or insignificant effect on education is not randomly distributed across countries. We provide robust evidence that minority religions are more likely to have a positive effect, and less likely to have a negative effect on the level of education of its members. This finding is in 
line with the theories that emphasize the role of religions as a club good. The finding may also be in line with theories that suggest that members of minority religions must invest in education to compensate for their minority status.

One may argue that our results capture the fact that different blends of the same religion with different implications for education are subsumed under the same name. For instance, Calvinists and Lutherans are pooled together under the label Protestantism, or Islam pools together Shia and Sunni Muslims. While we cannot fully dismiss that point, it only applies to a subset of religious denominations. It for instance does not apply to Catholicism, which is more centralized and therefore more uniform. Yet, our findings for Catholicism are in line with those obtained for other denominations. This is, however, food for further research. 


\section{References}

Akerlof, George A. and Kranton, Rachel E. 2000. "Economics and identity," Quarterly Journal of Economics, 115(3): 715-753.

Akerlof, George A., and Rachel E. Kranton. 2002. "Identity and schooling: Some lessons for the economics of education," Journal of Economic Literature 40(4): 1167-1201.

Alesina, A. and Paola Giuliano. 2015. "Culture and institutions," Journal of Economic Literature, 53(4): 898-944.

Arruñada, B. 2010. "Protestants and Catholics: Similar Work Ethic, Different Social Ethic," Economic Journal 120: 890-918.

Asadullah, Mohammad Niaz, and Nazmul Chaudhury. 2010. "Religious Schools, Social Values, and Economic Attitudes: Evidence from Bangladesh," World Development 38(2): 205-217.

Asadullah, Mohammad Niaz, Nazmul Chaudhury, and Amit Dar. 2007. "Student achievement conditioned upon school selection: Religious and secular secondary school quality in Bangladesh," Economics of Education Review 26(6): 648-659

Barro, R. and Jong-Wha Lee. 2013. "A new data set of educational attainment in the world, 1950-2010," Journal of Development Economics 104: 184-198.

Barro, Robert J, and Rachel M McCleary. 2006. "Religion and economy," The Journal of Economic Perspectives 20(2): 49-72.

Barro, Robert J, and Rachel M McCleary. 2003. "Religion and economic growth across countries," American Sociological Review 68: 760-781.

Barro, Robert J, and Rachel M. McCleary. 2005. "Which countries have state religions?" Quarterly Journal of Economics 120 (4): 1331-1370.

Becker, Sascha O., and Ludger Woessmann. 2009. "Was Weber Wrong? A Human Capital Theory of Protestant Economic History," Quarterly Journal of Economics 124(2): 531596.

Berman, Eli. 2000. "Sect, Subsidy, and Sacrifice: An Economist's View of Ultra-Orthodox Jews," Quarterly Journal of Economics 115(3): 905-953.

Bettendorf, L.; Dijkgraaf, E. 2010. "Religion and Income: Heterogeneity between Countries," Journal of Economic Behavior and Organization 74 (1-2): 12-29. 
Beyerlein, Kraig. 2004. "Specifying the Impact of Conservative Protestantism on Educational Attainment," Journal for the Scientific Study of Religion 43(4): 505-518.

Blunch, Niels-Hugo. 2007. "Human Capital and Religion in Ghana," Cambridge Working Papers in Economics 0770.

Bobrick, Benson. 2001. Wide as the waters: The story of the English Bible and the revolution it inspired. Simon \& Schuster.

Borooah, Vani K. and Sriya Iyer. 2005. "Vidya, Veda, and Varna: The influence of religion and caste on education in rural India," Journal of Development Studies 41(8): 13691404.

Botticini, Maristella, and Zvi Eckstein. 2005. "Jewish Occupational Selection: Education, Restrictions, or Minorities?” Journal of Economic History 65(4), 922-948.

Botticini, Maristella, and Zvi Eckstein. 2007. "From farmers to merchants, conversions and diaspora: Human capital and Jewish history," Journal of the European Economic Association 5(5):885-926.

Brenner Reuven, and Nicholas M. Kiefer, 1981. "The Economics of Diaspora: Discrimination and Occupational Structure," Economic Development and Cultural Change 29(3): 517534.

Brown, Sarah, and Karl Taylor. 2007. "Religion and education: evidence from the National Child Development Study,” Journal of Economic Behavior \& Organization 63(3):439460.

Chaney, Eric, 2011. "Islam and Human Capital Formation: Evidence from Pre-Modern Science," in Rachel M. McCleary (ed.), Oxford Handbook of the Economics of Religion, Oxford University Press, 81-91.

Chaudhary, Latika, and Jared Rubin. 2011. "Reading, Writing, and Religion: Institutions and Human Capital Formation,” Journal of Comparative Economics 39(1): 17-33.

Chiswick, Barry R. 1988. "Differences in Education and Earnings Across Racial and Ethnic Groups: Tastes, Discrimination, and Investments in Child Quality," Quarterly Journal of Economics 103(3): 571-597.

Cipolla, Carlo M. 1969. Literacy and Development in the West (Harmondsworth, UK: Penguin. 
Coate, Steven, and Glenn Loury. 1993. "Will Affirmative-Action Policies Eliminate Negative Stereotypes?" American Economic Review 83(5): 1220-1240.

Coleman, James S. 1988. "Social capital in the creation of human capital," American Journal of Sociology 94, S95-S120.

Czopp, Alexander M., Aaron C. Kay, and Sapna Cheryan. 2015. "Positive stereotypes are pervasive and powerful," Perspectives on Psychological Science 10(4): 451-463.

Darnell, Alfred and Darren E. Sherkat. 1997. "The Impact of Protestant Fundamentalism on Educational Attainment," American Sociological Review 62(2): 306-315.

Glaeser, E.L. and Glendon, S. 1998. "Incentives, predestination and free will," Economic Inquiry 36(3): 429-43.

Glaeser, Edward L., and Bruce I. Sacerdote. 2008. "Education and Religion," Journal of Human Capital 2(2): 188-215.

Go, Sun, and Peter Lindert. 2010. "The Uneven Rise of American Public Schools to 1850," Journal of Economic History 70(1): 1-26.

Goldin, Claudia, and Lawrence Katz. 2000. "Education and Income in the Early 20th Century: Evidence from the Prairies," Journal of Economic History 60(3): 782-818.

Guiso, Luigi, Paola Sapienza, and Luigi Zingales. 2003. "People's opium? Religion and economic attitudes," Journal of Monetary Economics 50(1):225-282.

Hanna, Rema N., and Leigh L. Linden. 2012. "Discrimination in grading," American Economic Journal: Economic Policy 4(4), 146-168.

Hanushek, Eric A, and Ludger Woessmann. 2008. "The role of cognitive skills in economic development," Journal of economic literature 46(3): 607-668.

Hillman, Arye L. 2007. "Economic and security consequences of supreme values," Public Choice 131(3): 259-280.

Hoff, Karla, and Priyanka Pandey. 2006. "Discrimination, social identity, and durable inequalities," American economic review 96(2), 206-211.

Hollander, Gideon, Kahana, Nava, and Tikva Lecker. 2003. "Religious and secular human capital: An economic model," Journal of Socio-Economics 32(5): 489-498.

Iannaccone, Laurence R., 1992. "Sacrifice and Stigma: Reducing Free-Riding in Cults, Communes, and Other Collectives," Journal of Political Economy 100(2): 271-291. 
Kranton, Rachel E. 2016. "Identity Economics 2016: Where Do Social Distinctions and Norms Come From?" American Economic Review 106(5): 405-409.

Kuran, Timur. 1996. "The discontents of Islamic economic morality," American Economic Review Papers and Proceedings 86(2): 438-442.

Kuran, Timur. 1997. "Islam and underdevelopment: an old puzzle revisited," Journal of Institutional and Theoretical Economics 153(1): 41-71.

Kuran, Timur. 2004. "Why the Middle East is economically underdeveloped: historical mechanisms of institutional stagnation," Journal of Economic Perspectives 18(3): 71-90.

Lehrer, Evelyn L. 1999. "Religion as a Determinant of Educational Attainment: An Economic Perspective," Social Science Research 28(4): 358-379.

Ling, Trevor. 1984. "Buddhism and education in Burma and Thailand," Religion 14(1): 5365 .

Luther, M., "An die Ratsherren aller Städte deutschen Landes, dass sie christliche Schulen aufrichten und halten sollen (To the Councilmen of All Cities in Germany That They Establish and Maintain Christian Schools)," in Dr. Martin Luthers Werke: Kritische Gesamtausgabe, Vol. 15 (Weimar, Germany: Verlag Hermann Böhlhaus Nachfolger [1524] 1899).

Luther, M., "Eine Predigt, daß man Kinder zur Schule halten solle (A Sermon on Keeping Children in School)," in Dr. Martin Luthers Werke: Kritische Gesamtausgabe, Vol. 30, Part 2 (Weimar, Germany: Verlag Hermann Böhlhaus Nachfolger [1530] 1909).

Markussen, Ingrid. 1990. "The development of writing ability in the Nordic countries in the eighteenth and nineteenth centuries," Scandinavian Journal of History 15(1-2): 37-63.

Marshall, M.G., K. Jaggers, and T.R. Gurr. 2011. "Polity IV Project: Political regime characteristics, and transitions, 1800-2010: Dataset users' manual," University of Maryland, Center for International Development and Conflict Management.

McClelland, V. Alan. "Wholeness, faith and the distinctiveness of the Catholic school," in McLaughlin, B.Terence, Joseph O'Keefe, and Bernadette O'Keeffe. The contemporary Catholic school: Context, identity, and diversity. Psychology Press, 1996, 155-161.

Mocan, Naci, and Luiza Pogorelova. 2014. "Compulsory schooling laws and formation of beliefs: education, religion and superstition,” NBER Working Paper 20557. 
Morey, Melanie M. and Piderit, John J. 2010. Catholic higher education: A culture in crisis. Oxford University Press, 2010.

Newhouse, David, and Beegle, Kathleen. (2006). "The effect of school type on academic achievement: Evidence from Indonesia," Journal of Human Resources 41(3): 529-557.

Offenbacher, Martin.1900 "Konfessionelle und soziale Schichtung. Eine Studie über die wirtschaftliche Lage der Katholiken und Protestanten in Baden," Volkswirtschaftliche Abhandlungen der Badischen Hochschulen, Bd. IV (5).

Oosterbeek, Hessel, and Bas van der Klaauw. 2013. "Ramadan, Fasting and Educational Outcomes," Economics of Education Review 34: 219-226.

Paul VI, 1965. Gravissimum Educationis [Declaration on Christian Education], accessed 13 July 2016.

http://www.vatican.va/archive/hist_councils/ii_vatican_council/documents/vatii_decl_19651028_gravissimum-educationis_en.html

Pius XI, 1929. Divini Illius Magistri [Encyclical on Christian education], accessed 13 July 2016.

http://w2.vatican.va/content/pius-xi/en/encyclicals/documents/hf_pxi_enc_31121929_divini-illius-magistri.html

Platteau, Jean-Philippe. 2008. "Religion, politics, and development: Lessons from the lands of Islam,” Journal of Economic Behavior \& Organization 68(2): 329-351.

Rosenthal, Robert, and Lenore Jacobson. 1968. "Pygmalion in the classroom," Urban Review 3(1), 16-20.

Sander, William. 2010. "Religious Background and Educational Attainment: The Effects of Buddhism, Islam, and Judaism," Economics of Education Review 29(3): 489-493.

Schaltegger, C, and B. Torgler. 2010. "Work ethic, Protestantism, and human capital," Economics Letters (107): 2, 99-101.

Shih, Margaret, Ambady, Nalimi, Richeson, Jennifer A., Fujita, Kentaro, and Gray, Heather M. (2002). "Stereotype performance boosts: the impact of self-relevance and the manner of stereotype activation," Journal of personality and social psychology, 83(3), $638-647$. 
Weber, Max, "Die protestantische Ethik und der 'Geist' des Kapitalismus", Archiv für Sozialwissenschaft und Sozialpolitik 20 (1904/1905), 1-54 and 21: 1-110; reprinted in Gesammelte Aufsätze zur Religionssoziologie, pp. 17-206, 1920; English translation as The Protestant Ethic and the Spirit of Capitalism, translated by Talcott Parsons (London, UK: Routledge Classics, [1930] 2001).

Woodberry, Robert D. 2011. "Religion and the Spread of Human Capital and Political Institutions: Christian Missions as a Quasi-Natural Experiment”, in Rachel M. McCleary (ed.), Oxford Handbook of the Economics of Religion, Oxford University Press, 111-131. 


\section{Tables}

Table 1: Descriptive Statistics:

Education Level, Religious Affiliation, Religiosity and Demographics

\section{Religious Denomination:}

Catholic

Christian, Protestant

Christian, Orthodox

Buddhist

Muslim

Jewish

Hindu

Other affiliations

No religious affiliation

0.133

\section{Religiosity:}

Religious Person (yes)

Goes to Religious Services at least once a Week

Goes to Religious Services once a Month

Goes to Religious Services once a year / only on Special Holidays

Goes to Religious Services less than once a year

\section{Education:}

Lower (elementary education and below)

Middle (intermediate \& full secondary)

Upper (lower \& upper-level tertiary certificate)

\section{Demographic Characteristics}

Age (years)

Female (yes)

0.508

Married (yes)

0.591

Social Class

3.356

Income (decile) 
Table 2: Education Level and Religious Affiliation, by Religion (Ordered Logit)

\begin{tabular}{|c|c|c|c|c|c|c|c|c|c|}
\hline & 2.1 & 2.2 & 2.3 & 2.4 & 2.5 & 2.6 & 2.7 & 2.8 & 2.9 \\
\hline & Catholic & Protestant & Jewish & Muslim & Orthodox & Hindu & Buddhist & Others & $\begin{array}{c}\text { No } \\
\text { Religion }\end{array}$ \\
\hline \multirow[t]{2}{*}{$\begin{array}{l}\text { Denominat } \\
\text { ion }\end{array}$} & 0.020 & -0.030 & $0.335^{* *}$ & $\begin{array}{c}- \\
0.548^{* * *}\end{array}$ & $0.166^{* * *}$ & 0.026 & -0.103 & 0.063 & $0.190^{* * *}$ \\
\hline & $(0.020)$ & $(0.022)$ & $(0.111)$ & $(0.031)$ & $(0.027)$ & $(0.063)$ & $(0.053)$ & $(0.035)$ & $(0.024)$ \\
\hline Religiosity & yes & yes & Yes & yes & yes & yes & Yes & yes & Yes \\
\hline Controls & yes & yes & Yes & yes & yes & yes & Yes & yes & Yes \\
\hline $\begin{array}{l}\text { Country } \\
\text { FE }\end{array}$ & yes & yes & Yes & yes & yes & yes & Yes & yes & Yes \\
\hline Years FE & yes & yes & Yes & yes & yes & yes & Yes & yes & Yes \\
\hline Pseudo R2 & 0.171 & 0.171 & 0.171 & 0.172 & 0.171 & 0.171 & 0.171 & 0.171 & 0.171 \\
\hline $\begin{array}{l}\text { Number of } \\
\text { Obs. }\end{array}$ & 147049 & 147049 & 147049 & 147049 & 147049 & $\begin{array}{c}14704 \\
9\end{array}$ & 147049 & $\begin{array}{c}14704 \\
9\end{array}$ & 147049 \\
\hline
\end{tabular}

Absolute standard errors are reported between brackets. ${ }^{*} p<0.05,{ }^{* *} p<0.01,{ }^{* * *} p<0.001$. 
Table 3: The distribution of estimates across countries

\begin{tabular}{|c|c|c|c|c|}
\hline Religious Affiliation & $\begin{array}{l}\text { Significant and } \\
\text { negative at } \\
\text { (Row \%) }\end{array}$ & $\begin{array}{c}\text { Not } \\
\text { significant at } \\
\text { (Row \%) }\end{array}$ & $\begin{array}{l}\text { Significant and } \\
\text { positive at } \\
\text { (Row \%) }\end{array}$ & $\begin{array}{l}\text { Number } \\
\text { of } \\
\text { countries }\end{array}$ \\
\hline & 3.1 . & 3.2 & 3.3 & 3.4 \\
\hline \multicolumn{5}{|l|}{$1 \%$ level } \\
\hline Catholic & 2.8 & 81.9 & 15.3 & 72 \\
\hline Christian, Protestant & 11.6 & 72.5 & 15.9 & 69 \\
\hline Christian, Orthodox & 13.2 & 69.8 & 17.0 & 53 \\
\hline Buddhist & 23.3 & 58.1 & 18.6 & 43 \\
\hline Muslim & 28.8 & 64.4 & 6.8 & 59 \\
\hline Jewish & 10.9 & 73.9 & 15.2 & 46 \\
\hline Hindu & 18.5 & 55.6 & 25.9 & 27 \\
\hline Other affiliations & 9.8 & 83.6 & 6.6 & 61 \\
\hline No religious affiliation & 1.4 & 86.1 & 12.5 & 72 \\
\hline \multicolumn{5}{|l|}{$5 \%$ level } \\
\hline Catholic & 8.3 & 68.1 & 23.6 & 72 \\
\hline Christian, Protestant & 17.4 & 56.5 & 26.1 & 69 \\
\hline Christian, Orthodox & 18.9 & 58.5 & 22.6 & 53 \\
\hline Buddhist & 23.3 & 51.2 & 25.6 & 43 \\
\hline Muslim & 39.0 & 52.5 & 8.5 & 59 \\
\hline Jewish & 13.0 & 65.2 & 21.7 & 46 \\
\hline Hindu & 18.5 & 51.9 & 29.6 & 27 \\
\hline Other affiliations & 13.1 & 75.4 & 11.5 & 61 \\
\hline No religious affiliation & 2.8 & 75.0 & 22.2 & 72 \\
\hline \multicolumn{5}{|l|}{$10 \%$ level } \\
\hline Catholic & 11.1 & 59.7 & 29.2 & 72 \\
\hline Christian, Protestant & 20.3 & 50.7 & 29.0 & 69 \\
\hline Christian, Orthodox & 20.8 & 56.6 & 22.6 & 53 \\
\hline Buddhist & 25.6 & 44.2 & 30.2 & 43 \\
\hline Muslim & 39.0 & 50.8 & 10.2 & 59 \\
\hline Jewish & 13.0 & 60.9 & 26.1 & 46 \\
\hline Hindu & 22.2 & 48.1 & 29.6 & 27 \\
\hline Other affiliations & 13.1 & 73.8 & 13.1 & 61 \\
\hline No religious affiliation & 5.6 & 62.5 & 31.9 & 72 \\
\hline
\end{tabular}


Table 4: Distribution of Estimates across Countries by Specification

\begin{tabular}{|c|c|c|c|c|c|c|c|c|c|}
\hline & Benchmark & $\begin{array}{c}\text { No } \\
\text { Religiosity }\end{array}$ & $\begin{array}{c}\text { No } \\
\text { Income }\end{array}$ & $\begin{array}{l}\text { Young } \\
(<41)\end{array}$ & $\begin{array}{c}\text { Old } \\
(>40)\end{array}$ & Men & Women & $\begin{array}{c}\text { Native } \\
\text { only } \\
\text { (wave 3) }\end{array}$ & $\begin{array}{c}\text { Raised } \\
\text { religiously } \\
\text { (wave 3) }\end{array}$ \\
\hline & 4.1 & 4.2 & 4.3 & 4.4 & 4.5 & 4.6 & 4.7 & 4.8 & 4.9 \\
\hline \multicolumn{10}{|l|}{ Catholic } \\
\hline$\%$ Significant and negative & 11.1 & 16.7 & 8.3 & 9.7 & 15.3 & 12.5 & 8.3 & 17.5 & 13.6 \\
\hline$\%$ Significant and positive & 29.2 & 27.8 & 29.2 & 23.6 & 22.2 & 27.8 & 22.2 & 12.5 & 9.1 \\
\hline$\%$ Not significant & 59.7 & 55.6 & 62.5 & 66.7 & 62.5 & 59.7 & 69.4 & 70 & 77.3 \\
\hline Identical to benchmark at: & & $91.0 \%$ & $92.3 \%$ & $70.5 \%$ & $75.6 \%$ & $74.4 \%$ & $75.6 \%$ & $87.2 \%$ & $93.6 \%$ \\
\hline \multicolumn{10}{|l|}{ Protestant } \\
\hline$\%$ Significant and negative & 20.3 & 20.3 & 20.3 & 15.9 & 17.4 & 17.4 & 17.4 & 17.5 & 15.9 \\
\hline$\%$ Significant and positive & 27.5 & 27.5 & 27.5 & 21.7 & 30.4 & 18.8 & 34.8 & 15 & 13.6 \\
\hline$\%$ Not significant & 52.2 & 52.2 & 52.2 & 62.3 & 52.2 & 63.8 & 47.8 & 67.5 & 70.5 \\
\hline Identical to benchmark at: & & $97.4 \%$ & $94.9 \%$ & $76.9 \%$ & $74.4 \%$ & $80.8 \%$ & $75.6 \%$ & $91.0 \%$ & $92.3 \%$ \\
\hline \multicolumn{10}{|l|}{ Orthodox } \\
\hline$\%$ Significant and negative & 20.8 & 20.8 & 22.6 & 22.6 & 22.6 & 18.9 & 9.4 & 17.2 & 18.8 \\
\hline$\%$ Significant and positive & 22.6 & 22.6 & 22.6 & 28.3 & 28.3 & 28.3 & 32.1 & 34.5 & 28.1 \\
\hline$\%$ Not significant & 56.6 & 56.6 & 54.7 & 49.1 & 49.1 & 52.8 & 58.5 & 48.3 & 53.1 \\
\hline Identical to benchmark at: & & $100.0 \%$ & $98.7 \%$ & $82.1 \%$ & $78.2 \%$ & $82.1 \%$ & $80.8 \%$ & $92.3 \%$ & $100.0 \%$ \\
\hline \multicolumn{10}{|l|}{ Buddhist } \\
\hline$\%$ Significant and negative & 25.6 & 25.6 & 27.9 & 23.3 & 18.6 & 25.6 & 25.6 & 8 & 11.1 \\
\hline$\%$ Significant and positive & 30.2 & 27.9 & 27.9 & 32.6 & 51.2 & 48.8 & 39.5 & 68 & 66.7 \\
\hline$\%$ Not significant & 44.2 & 46.5 & 44.2 & 44.2 & 30.2 & 25.6 & 34.9 & 24 & 22.2 \\
\hline Identical to benchmark at: & & $98.7 \%$ & $94.9 \%$ & $89.7 \%$ & $80.8 \%$ & $85.9 \%$ & $82.1 \%$ & $94.9 \%$ & $98.7 \%$ \\
\hline \multicolumn{10}{|l|}{ Muslim } \\
\hline$\%$ Significant and negative & 38.3 & 38.3 & 40 & 38.3 & 41.7 & 35 & 48.3 & 27.6 & 35.5 \\
\hline$\%$ Significant and positive & 11.7 & 15 & 11.7 & 16.7 & 23.3 & 15 & 20 & 34.5 & 16.1 \\
\hline$\%$ Not significant & 50 & 46.7 & 48.3 & 45 & 35 & 50 & 31.7 & 37.9 & 48.4 \\
\hline
\end{tabular}




\begin{tabular}{|c|c|c|c|c|c|c|c|c|c|}
\hline Identical to benchmark at: & & $97.4 \%$ & $91.0 \%$ & $74.4 \%$ & $73.1 \%$ & $84.6 \%$ & $70.5 \%$ & $87.2 \%$ & $94.9 \%$ \\
\hline \multicolumn{10}{|l|}{ Jewish } \\
\hline$\%$ Significant and negative & 13 & 10.9 & 15.2 & 17.4 & 21.7 & 10.9 & 26.1 & 10 & 8.8 \\
\hline$\%$ Significant and positive & 26.1 & 26.1 & 28.3 & 45.7 & 34.8 & 45.7 & 39.1 & 56.7 & 61.8 \\
\hline$\%$ Not significant & 60.9 & 63 & 56.5 & 37 & 43.5 & 43.5 & 34.8 & 33.3 & 29.4 \\
\hline Identical to benchmark at: & & $98.7 \%$ & $94.9 \%$ & $75.6 \%$ & $80.8 \%$ & $78.2 \%$ & $79.5 \%$ & $94.9 \%$ & $98.7 \%$ \\
\hline \multicolumn{10}{|l|}{ Hindu } \\
\hline$\%$ Significant and negative & 22.2 & 22.2 & 14.8 & 22.2 & 11.1 & 14.8 & 22.2 & 13.3 & 12.5 \\
\hline$\%$ Significant and positive & 29.6 & 33.3 & 29.6 & 40.7 & 59.3 & 48.1 & 48.1 & 60 & 68.8 \\
\hline$\%$ Not significant & 48.1 & 44.4 & 55.6 & 37 & 29.6 & 37 & 29.6 & 26.7 & 18.8 \\
\hline Identical to benchmark at: & & $98.7 \%$ & $96.2 \%$ & $88.5 \%$ & $89.7 \%$ & $92.3 \%$ & $88.5 \%$ & $96.2 \%$ & $97.4 \%$ \\
\hline \multicolumn{10}{|l|}{ Other Affiliations } \\
\hline$\%$ Significant and negative & 13.1 & 14.8 & 19.7 & 16.4 & 21.3 & 8.2 & 19.7 & 0 & 3 \\
\hline$\%$ Significant and positive & 13.1 & 14.8 & 13.1 & 21.3 & 18 & 21.3 & 16.4 & 23.3 & 27.3 \\
\hline$\%$ Not significant & 73.8 & 70.5 & 67.2 & 62.3 & 60.7 & 70.5 & 63.9 & 76.7 & 69.7 \\
\hline Identical to benchmark at: & & $97.4 \%$ & $92.3 \%$ & $73.1 \%$ & $80.8 \%$ & $79.5 \%$ & $79.5 \%$ & $93.6 \%$ & $98.7 \%$ \\
\hline \multicolumn{10}{|l|}{ No Religious Affiliation } \\
\hline$\%$ Significant and negative & 5.4 & 8.1 & 4.1 & 9.5 & 5.4 & 5.4 & 10.8 & 0 & 2.3 \\
\hline$\%$ Significant and positive & 33.8 & 32.4 & 36.5 & 10.8 & 35.1 & 27 & 25.7 & 20 & 22.7 \\
\hline$\%$ Not significant & 60.8 & 59.5 & 59.5 & 79.7 & 59.5 & 67.6 & 63.5 & 80 & 75 \\
\hline Identical to benchmark at: & & $88.5 \%$ & $93.6 \%$ & $66.7 \%$ & $73.1 \%$ & $78.2 \%$ & $71.8 \%$ & $89.7 \%$ & $94.9 \%$ \\
\hline
\end{tabular}


Table 5: Minority religions in our sample

\begin{tabular}{lccc}
\hline & $\begin{array}{c}\text { Number of countries } \\
\text { where the denomination } \\
\text { is present }\end{array}$ & $\begin{array}{c}\text { Number of countries } \\
\text { where the denomination } \\
\text { is a minority }\end{array}$ & $\begin{array}{c}\text { Percentage of countries } \\
\text { where the denomination } \\
\text { is a minority }\end{array}$ \\
\hline Catholic & 72 & 26 & 36.11 \\
Protestant & 69 & 32 & 46.38 \\
Muslim & 60 & 31 & 51.67 \\
Orthodox & 53 & 34 & 64.15 \\
Jewish & 46 & 46 & 100 \\
Buddhist & 43 & 36 & 83.72 \\
Hindu & 27 & 24 & 88.89 \\
\hline
\end{tabular}

Notes: A denomination is considered as a minority in a country if its share of followers in the country is smaller or equal to five-percent according to the World Values Survey 
Table 6: Impact of being a minority religion: alternative definitions of religious minorities

\begin{tabular}{|c|c|c|c|c|c|c|c|c|}
\hline $\begin{array}{l}\text { Definition of the minority dummy } \\
\text { Modality of the dependent variable }\end{array}$ & $\begin{array}{l}6.1) \\
<1 \%\end{array}$ & $\begin{array}{l}6.2) \\
<5 \%\end{array}$ & $\begin{array}{l}(6.3) \\
<10 \%\end{array}$ & $\begin{array}{c}(6.4) \\
<20 \%\end{array}$ & $\begin{array}{l}(6.5) \\
<30 \%\end{array}$ & $\begin{array}{l}(6.6) \\
<40 \%\end{array}$ & $\begin{array}{l}(6.7) \\
<50 \%\end{array}$ & $\begin{array}{c}(6.8) \\
\text { Share others }\end{array}$ \\
\hline $\begin{array}{l}\text { Positive and significant at } 10 \% \\
\text { Minority religion }\end{array}$ & $\begin{array}{l}0.467 * \\
(0.256) \\
\end{array}$ & $\begin{array}{c}0.574 * * \\
(0.282) \\
\end{array}$ & $\begin{array}{l}0.488^{*} \\
(0.295) \\
\end{array}$ & $\begin{array}{c}0.348 \\
(0.309) \\
\end{array}$ & $\begin{array}{c}0.737 * * \\
(0.364) \\
\end{array}$ & $\begin{array}{l}0.745^{*} \\
(0.395) \\
\end{array}$ & $\begin{array}{l}0.728^{*} \\
(0.442) \\
\end{array}$ & $\begin{array}{l}1.104 * * \\
(0.560)\end{array}$ \\
\hline $\begin{array}{l}\text { Negative and significant at } 10 \% \\
\text { Minority religion }\end{array}$ & $\begin{array}{l}-0.529 * \\
(0.275) \\
\end{array}$ & $\begin{array}{c}-0.753 * * * \\
(0.270) \\
\end{array}$ & $\begin{array}{c}-0.717 * * * \\
(0.272) \\
\end{array}$ & $\begin{array}{r}-0.521^{*} \\
(0.284) \\
\end{array}$ & $\begin{array}{l}-0.369 \\
(0.301) \\
\end{array}$ & $\begin{array}{r}-0.587 * \\
(0.307) \\
\end{array}$ & $\begin{array}{r}-0.619 * \\
(0.331) \\
\end{array}$ & $\begin{array}{c}-0.939 * * \\
(0.422) \\
\end{array}$ \\
\hline Observations & 370 & 370 & 370 & 370 & 370 & 370 & 370 & 370 \\
\hline Number of minority denominations & 179 & 229 & 250 & 272 & 292 & 301 & 315 & - \\
\hline
\end{tabular}

Table 7: Impact of being a minority religion: alternative specifications of first-stage regressions

\begin{tabular}{|c|c|c|c|c|c|c|c|}
\hline $\begin{array}{l}\text { Specification } \\
\text { Modality of the dep. var. }\end{array}$ & $\begin{array}{c}(7.1) \\
\text { No religiosity }\end{array}$ & $\begin{array}{c}(7.2) \\
\text { No income }\end{array}$ & $\begin{array}{l}(7.3) \\
<40\end{array}$ & $\begin{array}{l}(7.4) \\
>40\end{array}$ & $\begin{array}{l}(7.5) \\
\text { Men }\end{array}$ & $\begin{array}{c}(7.6) \\
\text { Women }\end{array}$ & $\begin{array}{c}(7.7) \\
\text { Only natives }\end{array}$ \\
\hline $\begin{array}{l}\text { Positive and significant at 10\% } \\
\text { Minority }\end{array}$ & $\begin{array}{l}0.476^{*} \\
(0.280) \\
\end{array}$ & $\begin{array}{c}0.418 \\
(0.277) \\
\end{array}$ & $\begin{array}{c}1.035^{* * *} * \\
(0.278) \\
\end{array}$ & $\begin{array}{c}1.723 * * * \\
(0.298) \\
\end{array}$ & $\begin{array}{c}1.354 * * * \\
(0.287) \\
\end{array}$ & $\begin{array}{c}1.361 * * * \\
(0.278) \\
\end{array}$ & $\begin{array}{c}2.665^{* * * *} \\
(0.504) \\
\end{array}$ \\
\hline $\begin{array}{l}\text { Negative and significant at 10\% } \\
\text { Minority }\end{array}$ & $\begin{array}{c}-0.875 * * * \\
(0.269)\end{array}$ & $\begin{array}{c}-0.796 * * * \\
(0.270) \\
\end{array}$ & $\begin{array}{l}0.0764 \\
(0.273) \\
\end{array}$ & $\begin{array}{l}0.0623 \\
(0.270) \\
\end{array}$ & $\begin{array}{l}-0.172 \\
(0.278)\end{array}$ & $\begin{array}{c}0.277 \\
(0.272) \\
\end{array}$ & $\begin{array}{l}0.0400 \\
(0.397) \\
\end{array}$ \\
\hline Observations & 370 & 370 & 370 & 370 & 370 & 370 & 208 \\
\hline
\end{tabular}

Standard errors in parentheses. ${ }^{* * *} \mathrm{p}<0.01, * * \mathrm{p}<0.05, * \mathrm{p}<0.1$. 
Table 8: Impact of being a minority religion with control variables

\begin{tabular}{|c|c|c|c|c|c|c|c|c|c|c|c|c|}
\hline Modality of the dep. var. & $(8.1)$ & $(8.2)$ & $(8.3)$ & $(8.4)$ & $(8.5)$ & $(8.6)$ & $(8.7)$ & $(8.8)$ & $(8.9)$ & $(8.10)$ & $(8.11)$ & $(8.12)$ \\
\hline \multicolumn{13}{|l|}{$\begin{array}{l}\text { Modality of the dep. var. } \\
\text { Positive and significant at } 10 \%\end{array}$} \\
\hline Minority religion $(<5 \%)$ & $\begin{array}{c}0.584 * * \\
(0.296)\end{array}$ & $\begin{array}{c}0.635^{* *} \\
(0.296)\end{array}$ & $\begin{array}{c}0.592 * * \\
(0.285)\end{array}$ & $\begin{array}{c}0.993 * * * \\
(0.324)\end{array}$ & $\begin{array}{c}0.598 * * \\
(0.283)\end{array}$ & $\begin{array}{c}0.694 * * \\
(0.317)\end{array}$ & $\begin{array}{c}1.202 * * * \\
(0.364)\end{array}$ & $\begin{array}{c}1.443 * * * \\
(0.404)\end{array}$ & $\begin{array}{c}1.040 * * * \\
(0.400)\end{array}$ & $\begin{array}{c}1.072 * * \\
(0.418)\end{array}$ & $\begin{array}{c}1.106 * * \\
(0.491)\end{array}$ & $\begin{array}{c}1.320 * * \\
(0.515)\end{array}$ \\
\hline State religion & $\begin{array}{l}0.0800 \\
(0.714)\end{array}$ & & & & & & $\begin{array}{c}0.217 \\
(0.868)\end{array}$ & $\begin{array}{c}0.275 \\
(0.875)\end{array}$ & & $\begin{array}{c}0.240 \\
(1.047)\end{array}$ & & $\begin{array}{l}2.965^{*} \\
(1.539)\end{array}$ \\
\hline Democracy & & $\begin{array}{c}-0.000818 \\
(0.0262)\end{array}$ & & & & & $\begin{array}{c}0.0142 \\
(0.0376)\end{array}$ & $\begin{array}{c}0.0109 \\
(0.0380)\end{array}$ & & & & \\
\hline GDP & & & $\begin{array}{c}-7.36 \mathrm{e}-06 \\
(1.02 \mathrm{e}-05)\end{array}$ & & & & $\begin{array}{l}-1.57 \mathrm{e}-05 \\
(1.66 \mathrm{e}-05)\end{array}$ & $\begin{array}{l}-1.38 \mathrm{e}-05 \\
(1.68 \mathrm{e}-05)\end{array}$ & & & & \\
\hline Years of schooling & & & & $\begin{array}{l}-0.0305 \\
(0.0547)\end{array}$ & & & $\begin{array}{r}-0.00152 \\
(0.0830)\end{array}$ & $\begin{array}{c}0.000887 \\
(0.0846)\end{array}$ & & & & \\
\hline Number of obs. in country $i$ & & & & & $\begin{array}{c}-0.000107 \\
(0.000111)\end{array}$ & & $\begin{array}{c}-0.000109 \\
(0.000121)\end{array}$ & $\begin{array}{c}-0.000109 \\
(0.000123)\end{array}$ & & & & \\
\hline \multicolumn{13}{|l|}{ Negative and significant at $10 \%$} \\
\hline Minority religion $(<5 \%)$ & $\begin{array}{c}-0.625 * * \\
(0.285)\end{array}$ & $\begin{array}{c}-0.566^{* *} \\
(0.285)\end{array}$ & $\begin{array}{c}-0.682 * * \\
(0.277)\end{array}$ & $\begin{array}{c}-0.531 * \\
(0.308)\end{array}$ & $\begin{array}{c}-0.768 * * * \\
(0.271)\end{array}$ & $\begin{array}{c}-1.048 * * * \\
(0.322)\end{array}$ & $\begin{array}{l}-0.277 \\
(0.343)\end{array}$ & $\begin{array}{l}-0.480 \\
(0.397)\end{array}$ & $\begin{array}{c}-1.344 * * * \\
(0.423)\end{array}$ & $\begin{array}{c}-1.176^{* * *} \\
(0.443)\end{array}$ & $\begin{array}{c}-1.471 * * * \\
(0.525)\end{array}$ & $\begin{array}{c}-1.457 * * * \\
(0.525)\end{array}$ \\
\hline State religion & $\begin{array}{c}0.753 \\
(0.506)\end{array}$ & & & & & & $\begin{array}{c}0.749 \\
(0.588)\end{array}$ & $\begin{array}{c}0.757 \\
(0.642)\end{array}$ & & $\begin{array}{c}1.081 \\
(0.842)\end{array}$ & & $\begin{array}{l}0.0658 \\
(1.140)\end{array}$ \\
\hline Democracy & & $\begin{array}{l}-0.0351 \\
(0.0254)\end{array}$ & & & & & $\begin{array}{c}0.0134 \\
(0.0379)\end{array}$ & $\begin{array}{c}0.0259 \\
(0.0405)\end{array}$ & & & & \\
\hline GDP & & & $\begin{array}{l}-1.74 \mathrm{e}-05 \\
(1.19 \mathrm{e}-05)\end{array}$ & & & & $\begin{array}{c}6.28 \mathrm{e}-06 \\
(1.92 \mathrm{e}-05)\end{array}$ & $\begin{array}{c}4.60 \mathrm{e}-06 \\
(1.95 \mathrm{e}-05)\end{array}$ & & & & \\
\hline Years of schooling & & & & $\begin{array}{c}-0.143 * * \\
(0.0585)\end{array}$ & & & $\begin{array}{l}-0.171^{*} \\
(0.0908)\end{array}$ & $\begin{array}{l}-0.169 * \\
(0.0930)\end{array}$ & & & & \\
\hline Number of obs. in country $i$ & & & & & $\begin{array}{c}6.25 \mathrm{e}-05 \\
(0.000106)\end{array}$ & & $\begin{array}{c}2.52 \mathrm{e}-05 \\
(0.000118)\end{array}$ & $\begin{array}{c}2.56 \mathrm{e}-05 \\
(0.000121)\end{array}$ & & & & \\
\hline Denomination fixed effects & no & no & no & no & no & yes & no & yes & yes & yes & yes & yes \\
\hline Country fixed effects & no & no & no & no & no & no & no & no & yes & yes & yes & yes \\
\hline Main alternative den. Dum. & no & no & no & no & no & no & no & no & no & no & yes & yes \\
\hline Observations & 370 & 335 & 359 & 301 & 370 & 370 & 286 & 286 & 370 & 370 & 370 & 370 \\
\hline
\end{tabular}

Standard errors in parentheses. ${ }^{* * *} \mathrm{p}<0.01,{ }^{* *} \mathrm{p}<0.05,{ }^{*} \mathrm{p}<0.1$ 
Figures

Fig. 1: The distribution of estimates across countries controlling for religiosity (10\% significance)

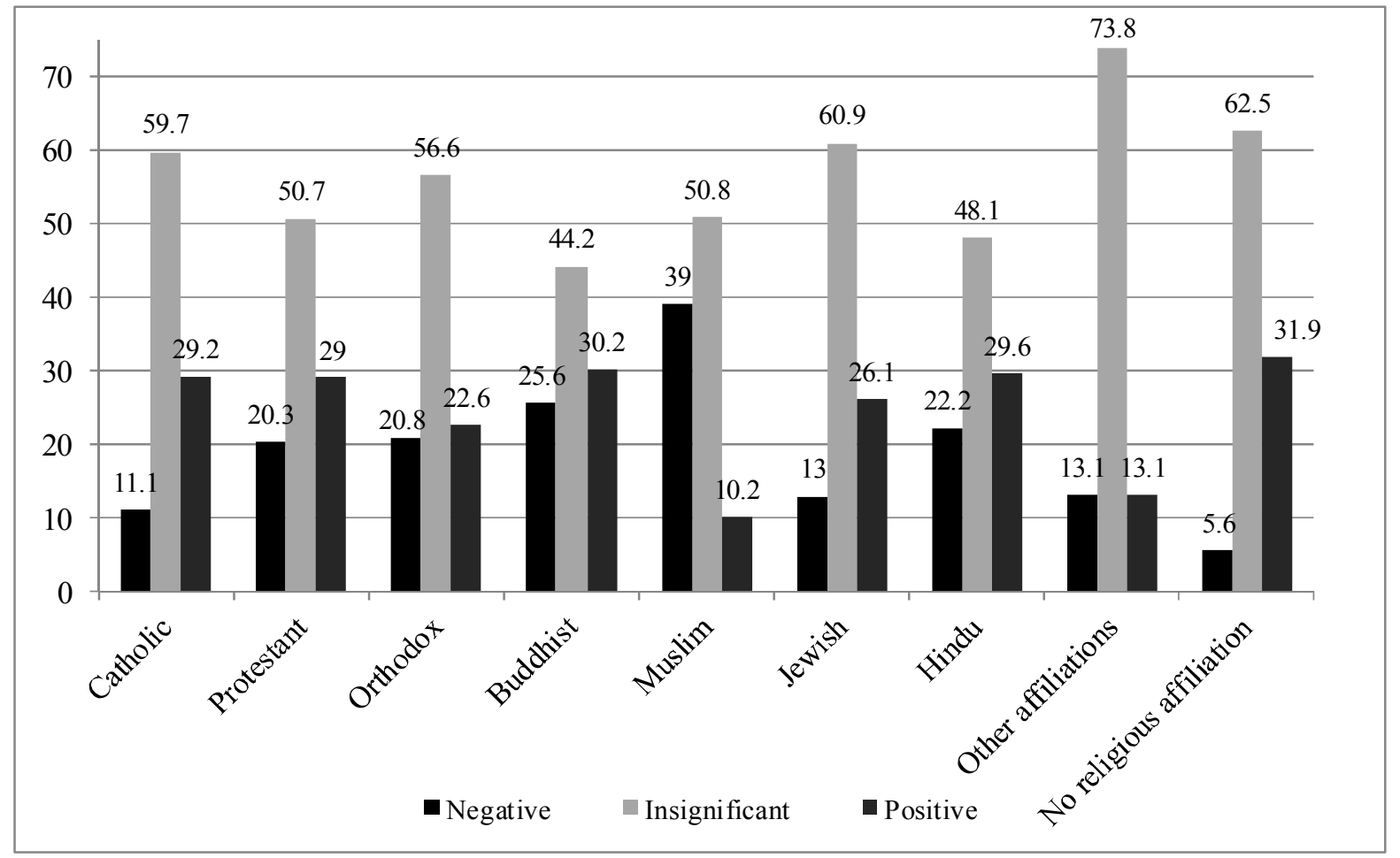


Appendix A: Additional Tables

Table A1: Sample Composition

\begin{tabular}{|c|c|c|c|c|c|c|c|}
\hline \multicolumn{2}{|c|}{ Europe } & \multicolumn{2}{|l|}{ Africa } & \multicolumn{2}{|c|}{ Asia / Oceania } & \multicolumn{2}{|c|}{ Americas } \\
\hline Country & Obs. & Country & Obs. & Country & Obs. & Country & Obs. \\
\hline Albania $^{\# *}$ & 1,811 & Algeria* & 378 & Armenia ${ }^{\#}$ & 1,622 & Argentina ${ }^{\#} *$ & 1,929 \\
\hline Andorra $\$$ & 878 & Burkina Faso $\$$ & 1,087 & Australia $^{\#} \$$ & 2,780 & $\mathrm{Brazil}^{\# \text { \$ }}$ & 2,360 \\
\hline Belarus $^{\#}$ & 1,409 & Egypt*\$ & 5,628 & Azerbaijan ${ }^{\#}$ & 1,545 & Canada* $\$$ & 2,919 \\
\hline Bosnia and & & Ethiopia $^{\$}$ & 1,337 & Bangladesh $^{\#}$ * & 2,680 & Chile $^{\# * \$}$ & 2,580 \\
\hline Herzegovina $^{\# *}$ & 1,847 & Ghana $\$$ & 1,379 & China*\$ & 1,091 & Colombia $^{\#}$ & 2,866 \\
\hline Bulgaria ${ }^{\# \$}$ & 1,518 & Mali $^{\$}$ & 894 & Hong Kong\$ & 1,043 & Dominican & \\
\hline Cyprus\$ & 1,012 & Morocco* & 568 & $\operatorname{India}^{\#} * \$$ & 4,711 & Republic $^{\#}$ & 282 \\
\hline Czech Republic ${ }^{\#}$ & 783 & Nigeria $^{\# *}$ & 3,402 & Indonesia*\$ & 2,274 & El Salvador ${ }^{\#}$ & 926 \\
\hline Estonia $^{\#}$ & 802 & Rwanda $\$$ & 1,331 & Iran*\$ & 4,112 & Mexico \# * & 2,629 \\
\hline Finland $d^{\# \$}$ & 1,554 & $\begin{array}{l}\text { South Africa } \\
* \$\end{array}$ & 6,745 & Iraq*\$ & 4,227 & Peru $\# * \$$ & 3,509 \\
\hline Georgia & 3,223 & Tanzania* & 975 & Japan* $\$$ & 1,687 & Puerto Rico $\# *$ & 1,483 \\
\hline Germany $^{\# ~ \$ ~}$ & 3,000 & Uganda* & 520 & Jordan* & 1,095 & Trinidad and & \\
\hline Italy $\$$ & 602 & Zambia $^{\$}$ & 1,023 & Kyrgyzstan* & 921 & Tobago $\$$ & 921 \\
\hline Latvia $^{\#}$ & 906 & Zimbabwe* & 748 & $\begin{array}{l}\text { New Zealand } \\
\# \$\end{array}$ & 1,463 & $\begin{array}{l}\text { United } \\
\text { States } \# * \$\end{array}$ & 3,054 \\
\hline Lithuania $^{\#}$ & 816 & & & Pakistan * & 1,168 & Uruguay \# \$ & 1,202 \\
\hline Macedonia $^{\#} *$ & 1,329 & & & Philippines* & 1,082 & Venezuela ${ }^{\# *}$ & 1,866 \\
\hline Moldova $^{\#} * \$$ & 2,634 & & & Saudi Arabia* & 1,198 & & \\
\hline Norway \# \$ & 1,766 & & & South Korea $\$$ & 1,191 & & \\
\hline Poland $^{\# \$}$ & 1,777 & & & Taiwan $^{\# ~ \$ ~}$ & 1,175 & & \\
\hline $\begin{array}{l}\text { Romania }{ }^{\# ~} \\
\text { Russian }\end{array}$ & 2,581 & & & Thailand $^{\$}$ & 1,480 & & \\
\hline Federation $^{\#}$ & 1,441 & & & Vietnam $* \$$ & 2,215 & & \\
\hline $\begin{array}{l}\text { Serbia } \\
\text { Serbia and }\end{array}$ & 974 & & & & & & \\
\hline Montenegro $^{\# *}$ & 2,770 & & & & & & \\
\hline Slovakia ${ }^{\#}$ & 859 & & & & & & \\
\hline Slovenia $\$$ & 764 & & & & & & \\
\hline Spain $^{\#} * \$$ & 2,644 & & & & & & \\
\hline Sweden $^{\#} * \$$ & 2,306 & & & & & & \\
\hline Switzerland ${ }^{\# \text { \$ }}$ & 1,837 & & & & & & \\
\hline Turkey $\# * \$$ & 5,360 & & & & & & \\
\hline Ukraine $^{\# \$}$ & 2,545 & & & & & & \\
\hline Total & 51,748 & Total & 26,015 & Total & 40,760 & Total & 28,526 \\
\hline
\end{tabular}

Note: Sample Wave: \# 1994-1999, * 1999-2004, \$ 2005-2007. 
Table A2: Country-denomination-specific Coefficients: Sign and Statistical Significance at 10\%

\begin{tabular}{|c|c|c|c|c|c|c|c|c|c|}
\hline $\begin{array}{l}\text { Country / } \\
\text { Denomination }\end{array}$ & Catholic & Protestant & Orthodox & Buddhist & Hindu & Jewish & Muslim & Others & $\begin{array}{c}\text { No } \\
\text { Relig. }\end{array}$ \\
\hline Albania & Not Sign. & Not Sign. & + & Not Pres. & Not Pres. & Not Sign. & - & + & - \\
\hline Algeria & Not Pres. & Not Pres. & Not Pres. & Not Pres. & Not Pres. & Not Pres. & Not Pres. & Not Pres. & + \\
\hline Andorra & - & Not Sign. & + & Not Pres. & Not Sign. & Not Pres. & Not Sign. & + & Not Sign. \\
\hline Azerbaijan & Not Sign. & Not Sign. & Not Sign. & Not Pres. & Not Pres. & Not Sign. & - & Not Pres. & + \\
\hline Argentina & Not Sign. & - & + & + & + & Not Sign. & Not Pres. & Not Sign. & Not Sign. \\
\hline Australia & - & Not Sign. & Not Sign. & Not Sign. & + & + & Not Sign. & Not Sign. & + \\
\hline Bangladesh & Not Sign. & Not Sign. & - & Not Sign. & Not Sign. & + & Not Sign. & Not Pres. & Not Sign. \\
\hline Armenia & Not Sign. & + & Not Sign. & Not Pres. & Not Pres. & Not Pres. & Not Pres. & Not Sign. & Not Sign. \\
\hline $\begin{array}{l}\text { Bosnia and } \\
\text { Herzegovina }\end{array}$ & Not Sign. & Not Sign. & Not Sign. & Not Pres. & Not Pres. & Not Sign. & Not Sign. & Not Pres. & Not Sign. \\
\hline Brazil & Not Sign. & - & - & Not Sign. & Not Pres. & + & Not Pres. & + & Not Sign. \\
\hline Bulgaria & Not Sign. & Not Sign. & + & - & Not Sign. & + & - & + & Not Sign. \\
\hline Belarus & - & Not Sign. & Not Sign. & Not Pres. & Not Pres. & Not Pres. & Not Sign. & Not Pres. & Not Sign. \\
\hline Canada & - & + & Not Sign. & + & Not Sign. & Not Sign. & Not Sign. & Not Sign. & Not Sign. \\
\hline Chile & Not Sign. & - & Not Pres. & Not Pres. & - & Not Sign. & Not Pres. & Not Sign. & + \\
\hline China & + & Not Sign. & - & Not Sign. & Not Pres. & Not Pres. & Not Sign. & Not Pres. & Not Sign. \\
\hline Taiwan & + & Not Sign. & Not Pres. & Not Sign. & Not Pres. & Not Pres. & + & Not Sign. & + \\
\hline Colombia & Not Sign. & Not Sign. & Not Pres. & Not Pres. & Not Pres. & + & Not Pres. & Not Sign. & Not Sign. \\
\hline Cyprus & Not Sign. & + & + & Not Pres. & Not Pres. & + & - & Not Sign. & + \\
\hline Czech republic & Not Sign. & Not Sign. & Not Pres. & Not Pres. & Not Pres. & Not Pres. & Not Pres. & Not Pres. & Not Sign. \\
\hline Dominican Republic & Not Sign. & Not Sign. & Not Pres. & Not Pres. & Not Pres. & Not Pres. & Not Pres. & Not Sign. & Not Sign. \\
\hline El Salvador & + & - & Not Pres. & Not Sign. & Not Pres. & Not Pres. & Not Pres. & Not Pres. & Not Sign. \\
\hline Ethiopia & + & + & - & - & Not Pres. & Not Sign. & - & Not Sign. & Not Sign. \\
\hline Estonia & Not Sign. & Not Sign. & Not Sign. & + & Not Pres. & Not Pres. & Not Sign. & Not Pres. & - \\
\hline Finland & Not Sign. & - & Not Sign. & Not Pres. & Not Pres. & Not Sign. & Not Sign. & + & + \\
\hline Georgia & Not Sign. & Not Sign. & Not Sign. & - & Not Sign. & - & Not Sign. & Not Sign. & Not Sign. \\
\hline
\end{tabular}




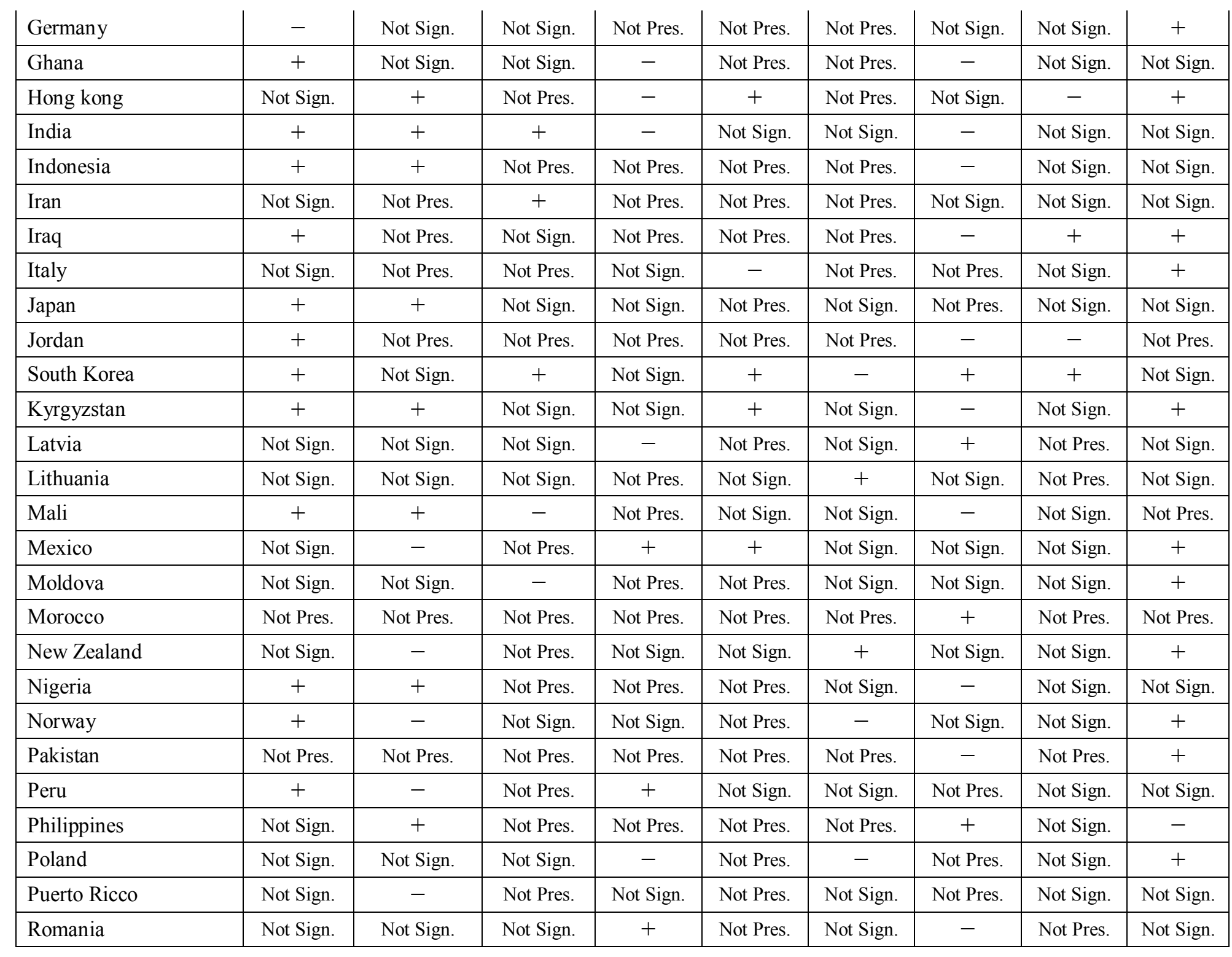




\begin{tabular}{|c|c|c|c|c|c|c|c|c|c|}
\hline Russian federation & + & + & Not Sign. & + & Not Pres. & + & Not Sign. & Not Pres. & Not Sign. \\
\hline Rwanda & - & Not Sign. & - & + & Not Pres. & - & Not Sign. & - & Not Sign. \\
\hline Saudi Arabia & Not Pres. & Not Pres. & Not Pres. & Not Pres. & Not Sign. & Not Pres. & Not Sign. & Not Sign. & - \\
\hline Slovakia & Not Sign. & Not Sign. & Not Sign. & Not Pres. & Not Pres. & Not Pres. & Not Pres. & Not Sign. & Not Sign. \\
\hline Vietnam & - & Not Sign. & - & Not Sign. & Not Pres. & - & Not Pres. & - & + \\
\hline Slovenia & Not Sign. & Not Sign. & - & + & Not Pres. & Not Pres. & Not Sign. & Not Sign. & + \\
\hline South Africa & Not Sign. & Not Sign. & - & Not Sign. & - & + & Not Sign. & Not Sign. & Not Sign. \\
\hline Zimbabwe & Not Sign. & Not Sign. & Not Sign. & Not Pres. & Not Pres. & Not Pres. & Not Sign. & Not Sign. & Not Sign. \\
\hline Spain & Not Sign. & Not Sign. & Not Pres. & Not Sign. & Not Pres. & Not Pres. & - & Not Sign. & Not Sign. \\
\hline Sweden & + & - & Not Sign. & - & Not Pres. & Not Sign. & Not Sign. & Not Sign. & + \\
\hline Switzerland & - & Not Sign. & + & + & + & Not Sign. & Not Sign. & Not Sign. & + \\
\hline Thailand & Not Pres. & - & Not Pres. & - & Not Pres. & Not Pres. & + & - & Not Sign. \\
\hline Trinidad and Tobago & + & Not Sign. & Not Sign. & Not Sign. & - & Not Pres. & Not Sign. & - & Not Sign. \\
\hline Turkey & Not Sign. & Not Sign. & Not Sign. & Not Pres. & Not Pres. & Not Sign. & Not Sign. & Not Sign. & + \\
\hline Uganda & Not Sign. & Not Sign. & Not Pres. & Not Pres. & Not Pres. & Not Pres. & Not Sign. & Not Sign. & Not Sign. \\
\hline Ukraine & Not Sign. & + & Not Sign. & + & - & Not Sign. & Not Sign. & Not Pres. & + \\
\hline Macedonia & Not Sign. & + & + & Not Pres. & Not Pres. & Not Sign. & - & Not Sign. & + \\
\hline Egypt & Not Pres. & Not Pres. & Not Pres. & Not Pres. & Not Pres. & Not Pres. & - & + & Not Pres. \\
\hline Tanzania & + & + & Not Sign. & Not Pres. & Not Pres. & Not Sign. & - & Not Sign. & Not Sign. \\
\hline United states & Not Sign. & + & Not Sign. & Not Sign. & Not Sign. & + & + & - & Not Sign. \\
\hline Burkina Faso & + & + & - & Not Pres. & - & + & - & - & Not Sign. \\
\hline Uruguay & Not Sign. & - & Not Pres. & + & Not Pres. & Not Sign. & Not Pres. & Not Sign. & Not Sign. \\
\hline Venezuela & Not Sign. & - & Not Sign. & + & + & Not Pres. & Not Pres. & Not Sign. & Not Sign. \\
\hline Serbia and Montenegro & Not Sign. & Not Sign. & Not Sign. & - & Not Pres. & Not Sign. & - & Not Sign. & Not Sign. \\
\hline Zambia & Not Sign. & + & + & Not Sign. & Not Sign. & Not Pres. & - & Not Sign. & Not Sign. \\
\hline Serbia & Not Sign. & Not Sign. & + & Not Pres. & Not Pres. & Not Sign. & - & Not Pres. & Not Sign. \\
\hline
\end{tabular}


Number of

Countries/Regression

(by denomination):

69

53

43

60
27 